\title{
الفصل في الشق المستعجل لطلب وقف تنفيذ القرار الاداري
}

Doi: $10.23918 /$ ilic2021.16

د. كاوه ياسين سليم ـ قسم الادارة القانونية ـ المعهد التقني خبات - جامعة اربيل التقنية ـ اربيل ـ العراق

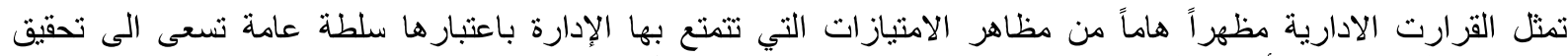

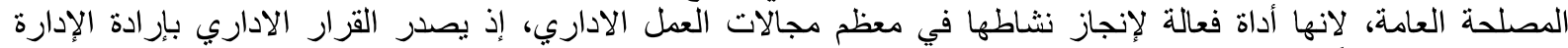

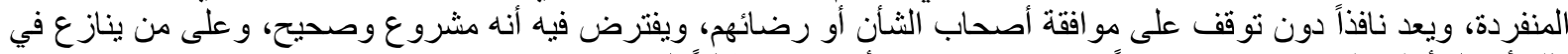

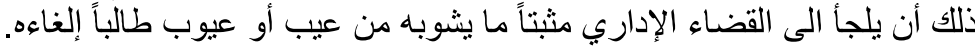

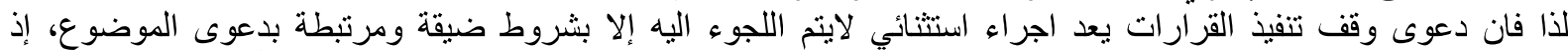

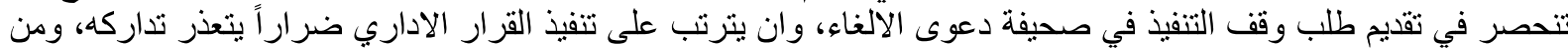

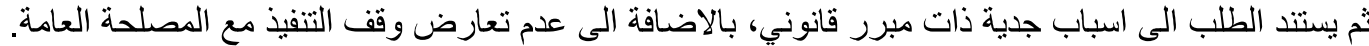

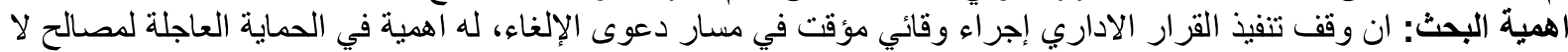

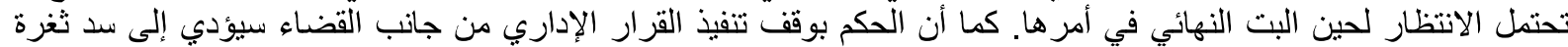

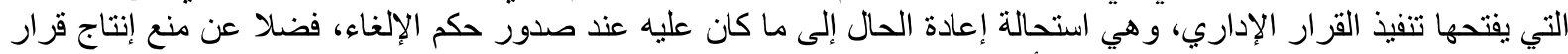

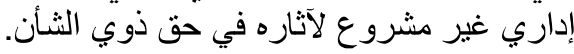

اهداف البحث

1- حاجة مكتبات القانون لمثل هذه الدراسات المتخصصة في مجال الإستعجال أمام القضاء الإداري في ظل نظام القضاء المزدوج .

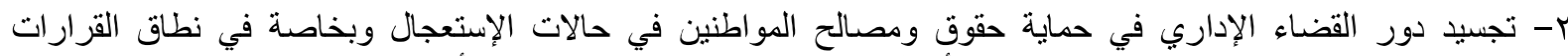

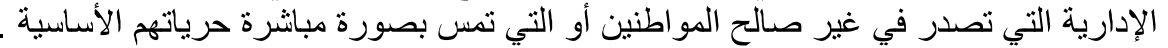

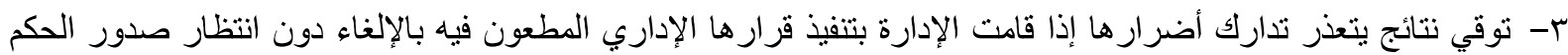
القضائي. توني

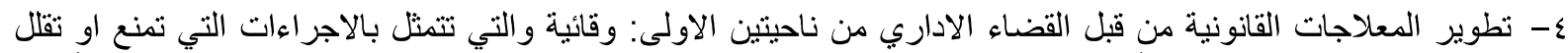
من إحتمال إصابة صاحب الثأن بضرر يتعذر تداركه. من الناحية الثانية الوسائل التي تعالج عدم قيام الإدارة بتنفيذ الأوامر الألئ المستعجلة.

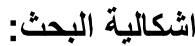

- مدى تطبيق نظام وقف تنفيذ القرارات الإدارية في القضاء الإداري العر اقي واقليم كوردستان؟

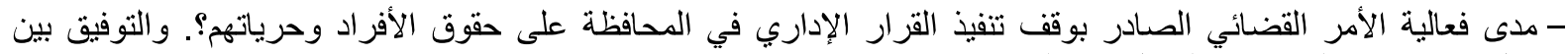
مصالح الادارة في المحافظة على الإنى المرفق العام.

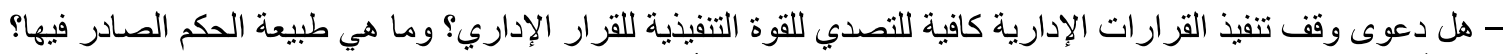

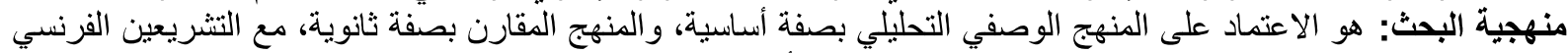

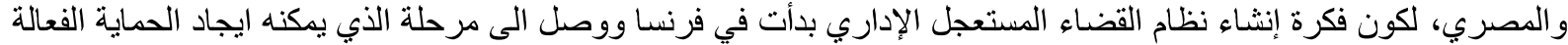

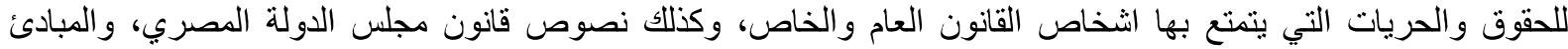

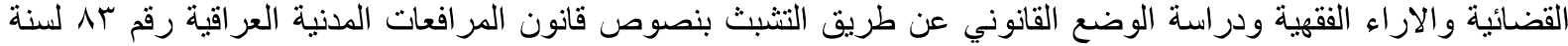

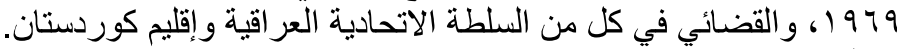

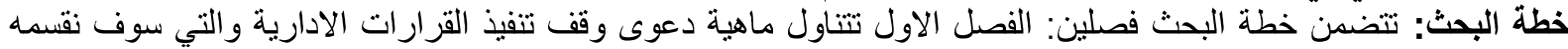

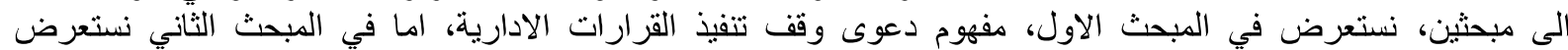

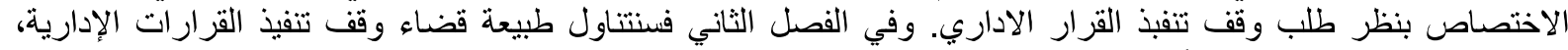

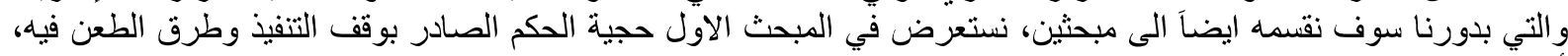

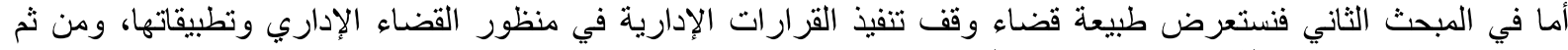

\section{الفصل الاول}

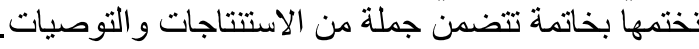

\section{ماهية دعوى وقف تنفيذ القرارات الادارية}

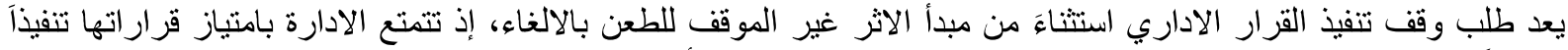

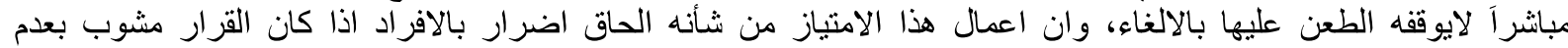

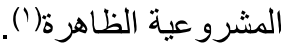
ان معرفة ماهية دعوى وقف تنفيذ القرار الاداري، يتطلب منا البحث عن مفهوم دعوى وقف تنفيذ القرارات الادارية ومن ثم الاختصاص بنظر طلب وقف تنفيذ القرارات الادارية وذلك في مبحثين على النحو التالي: 


\section{المبحث الاول}

مفهوم دعوى وقف تنفيذ القرارات الادارية

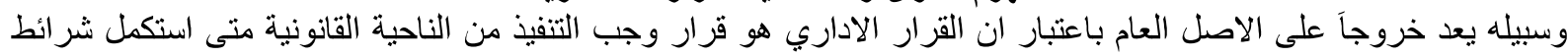

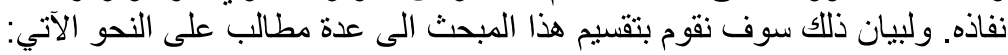

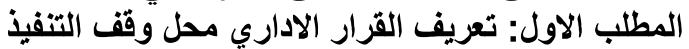

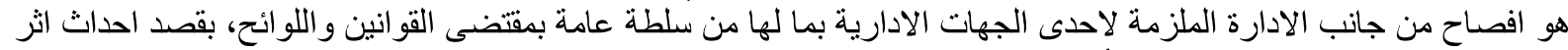

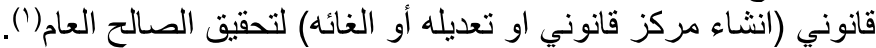

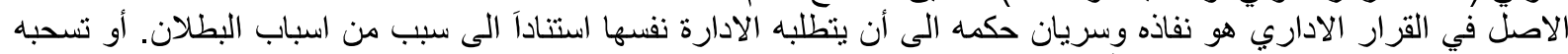

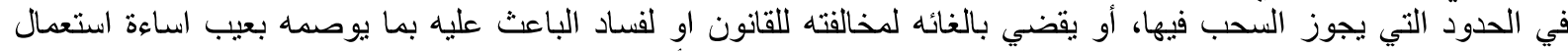

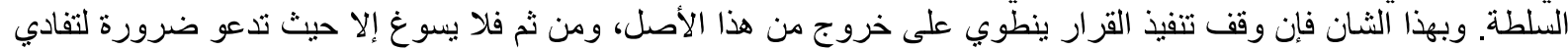

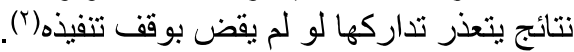

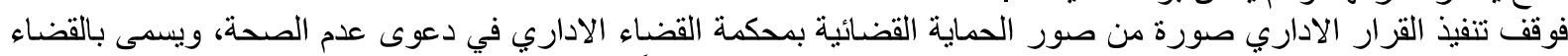

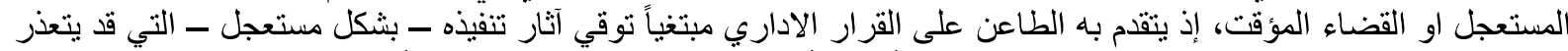

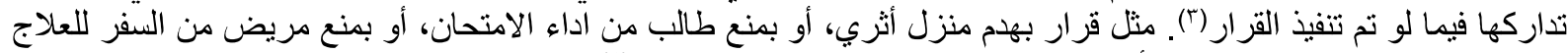

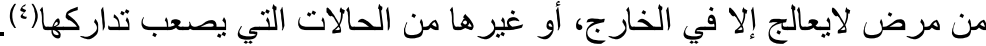

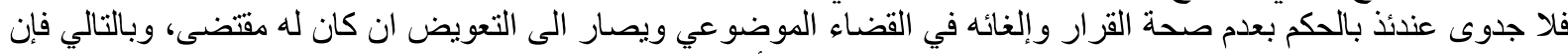

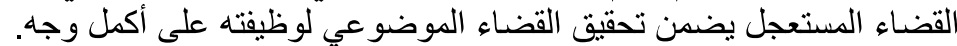

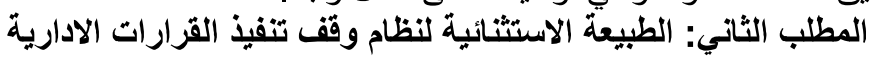

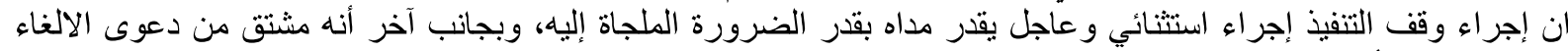

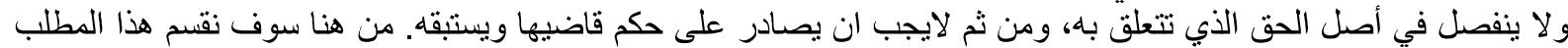

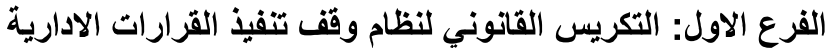

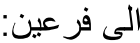

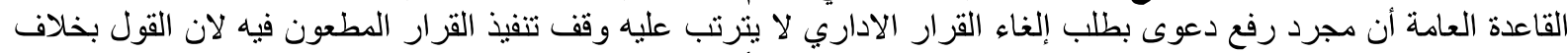

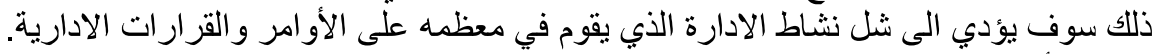

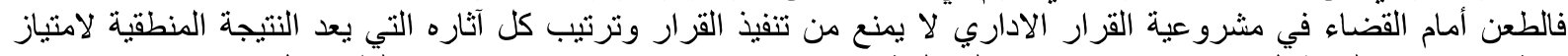

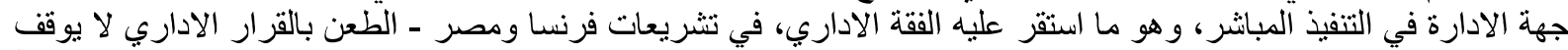

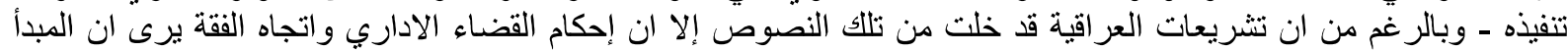

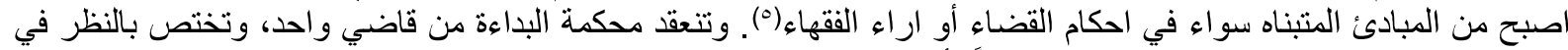

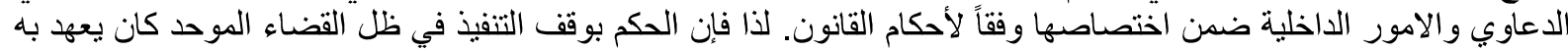

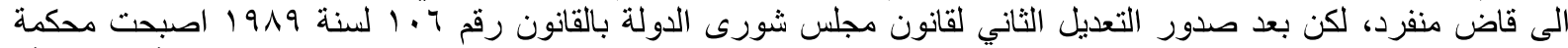

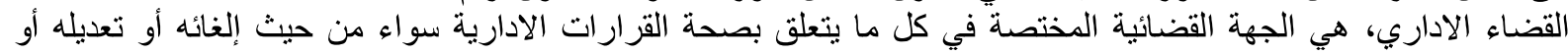

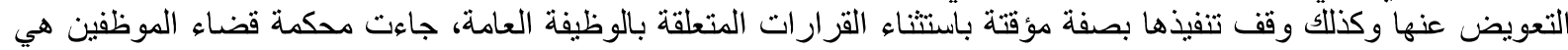

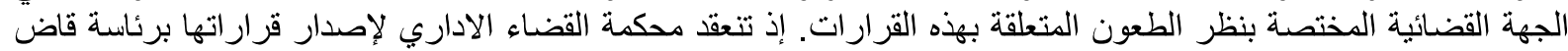

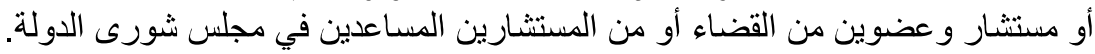

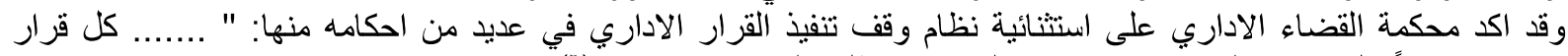

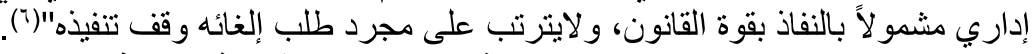

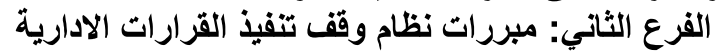

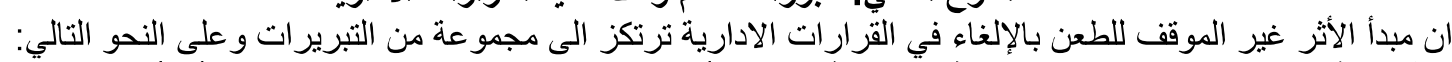

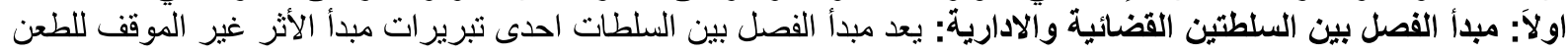

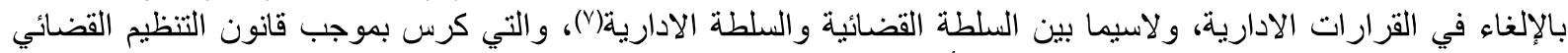

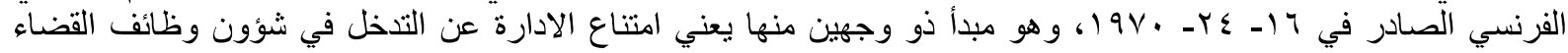

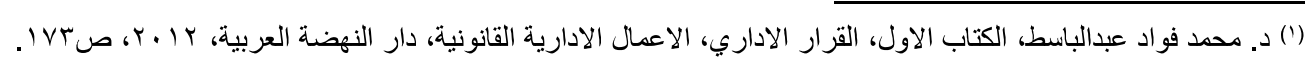

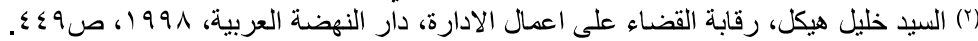

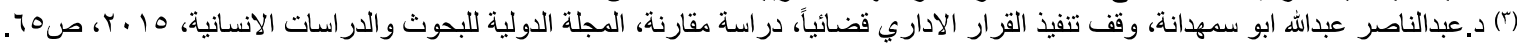

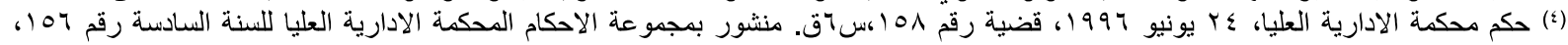

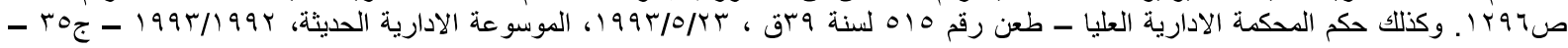

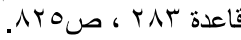

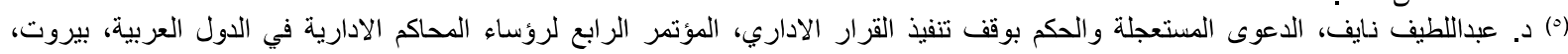

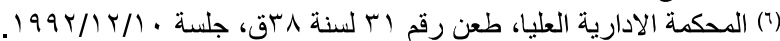

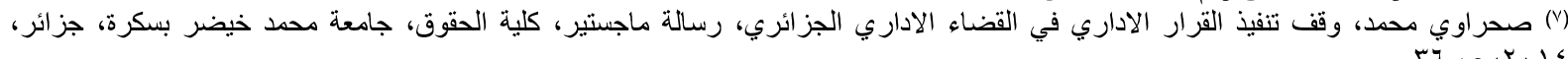


الاداري، ومن جهة أخرى ألا يتذخل القاضي في وظائف الادارة(')، وذلك على اسلس أنه إذا كان رفع الدعوى القضائية أو مجرد

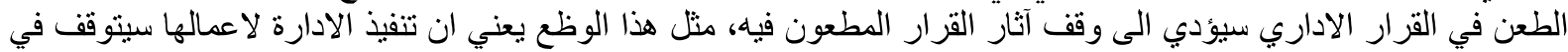

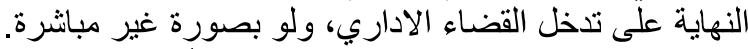

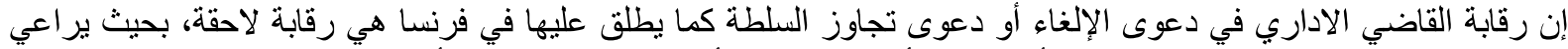

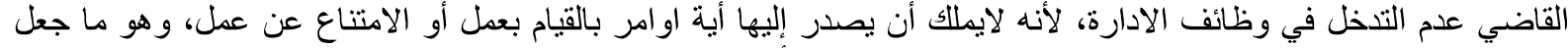

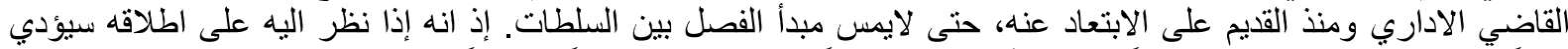

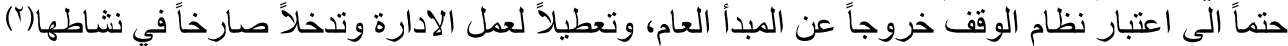

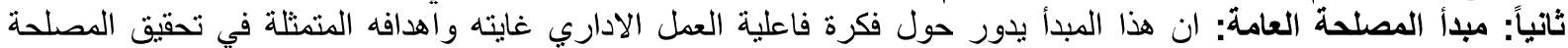

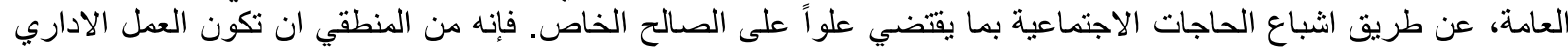

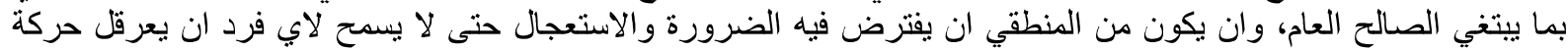

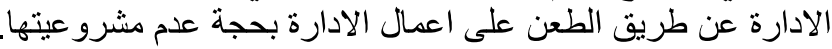

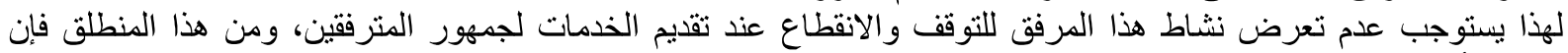

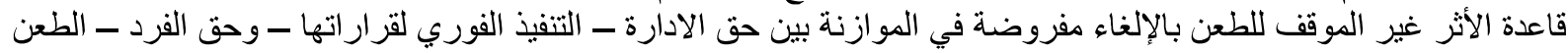

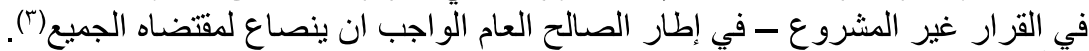

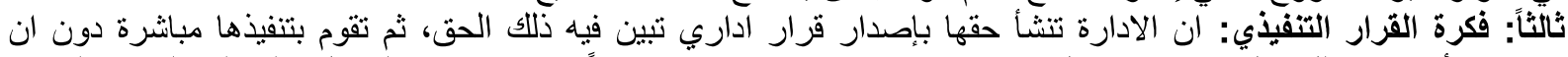

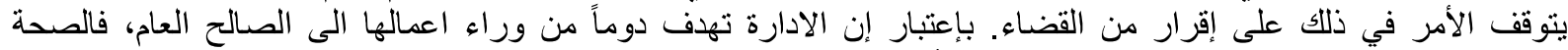

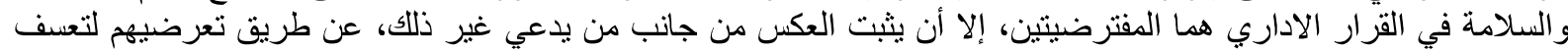

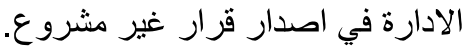

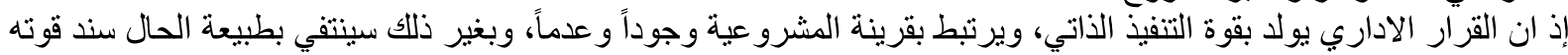
التنفيذية الذاتية.

\section{المبحث الثاني \\ الاختصاص بنظر طلب وقف تنفيذ القران القرار الاداري}

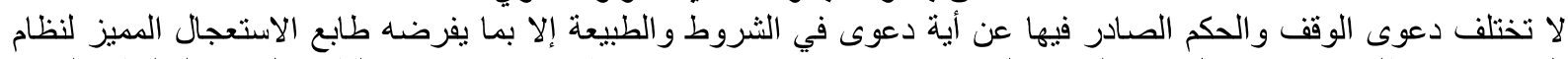

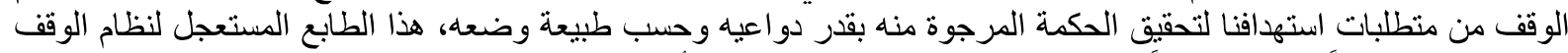

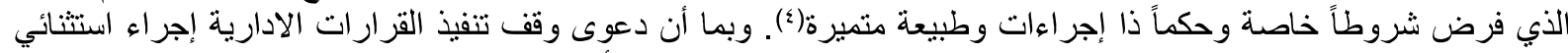

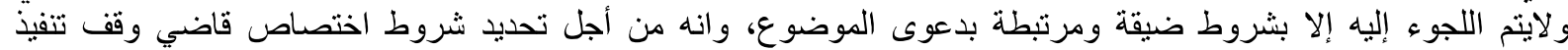

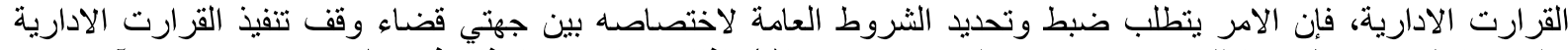
و الثروط الخاصة بكل جهة للقضاء بوقف تنفيذ القرارات الادارية('). لذلك سوف نتناول ذلك في مطلبين وعلى النحو الآتي: المطلب الاول: شروط وقف تنفيذ القرارات الادارية

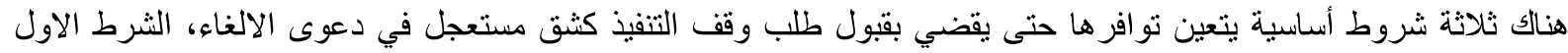

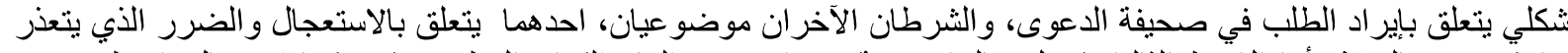

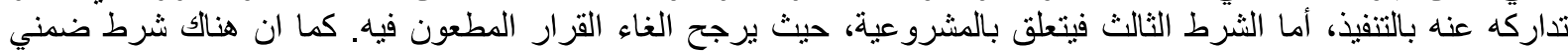

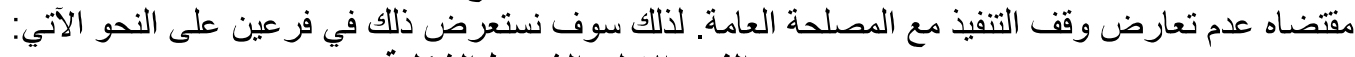
الفرع الاول: الثروط الثنكلية

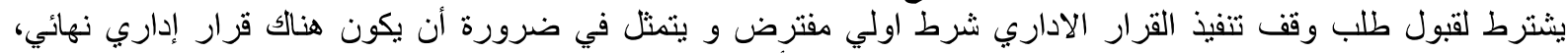

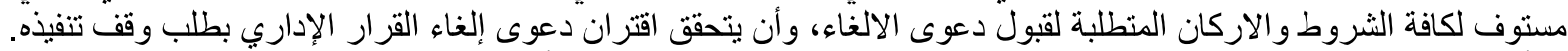

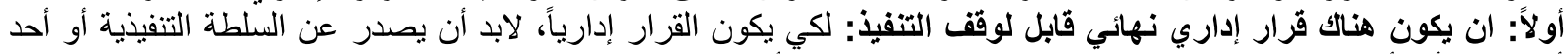

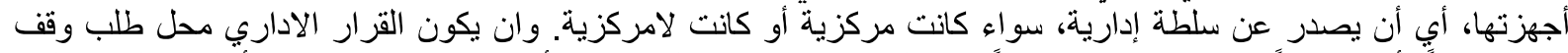

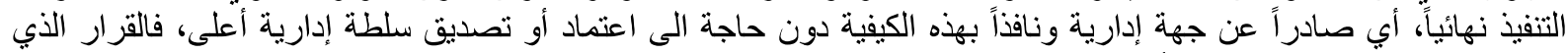

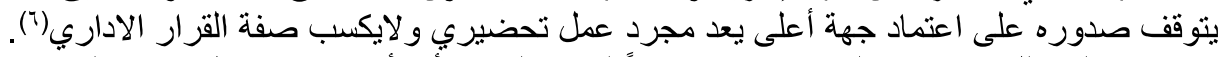

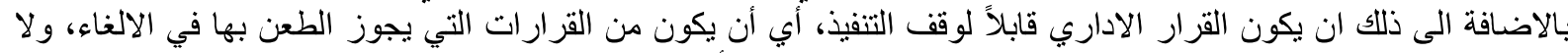

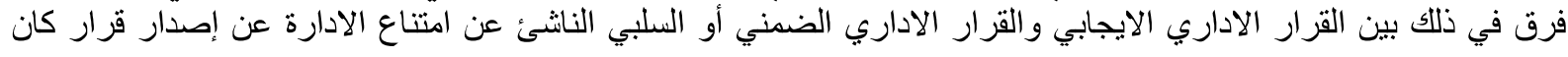

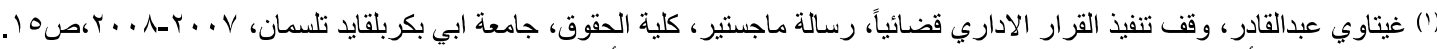

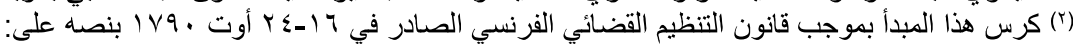

"Les fonctions judiciaires sont distinctes et demeuront toujours séparées de fonction administratives"

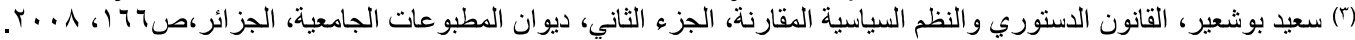

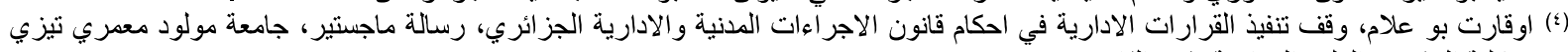

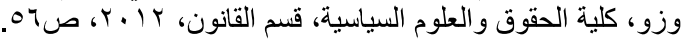

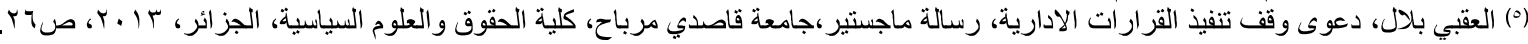

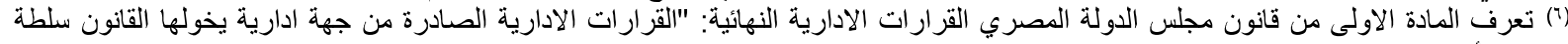
البت في أمر بغير حاجة الى تصديق سلطة اعلى النى، وقرار الت سلطة التصديق والاعتماد. 
من الواجب عليها قانوناً إصداره طبقاً للقوانين واللوائح، دنها الامتناع عن استخراج جواز سفر، أو المنع من السفر، أو الامتناع

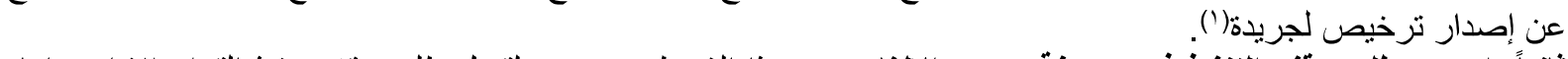

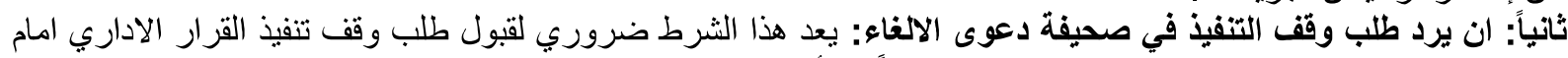

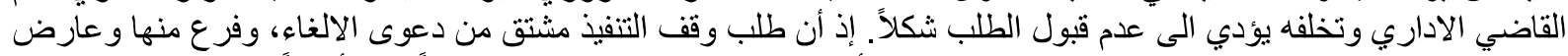

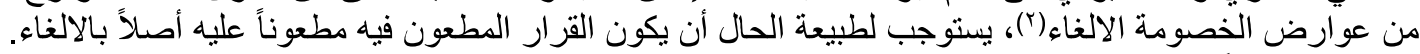

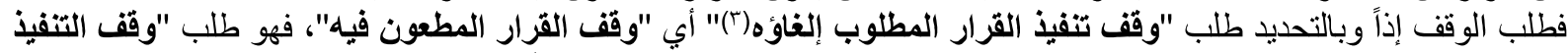

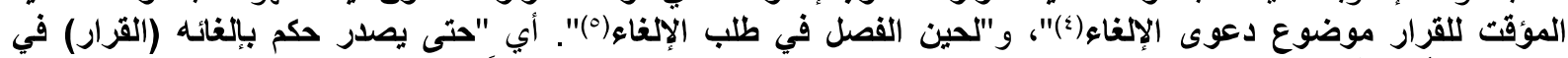

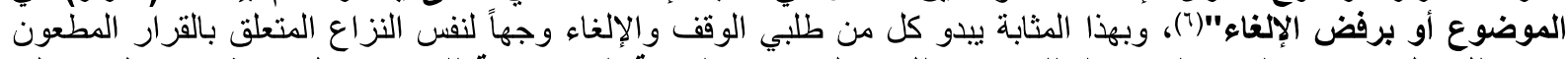

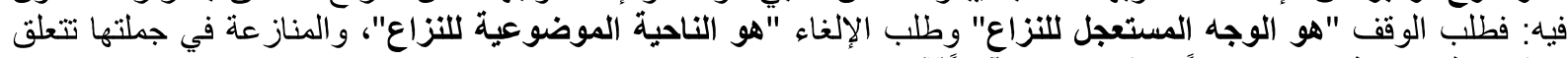

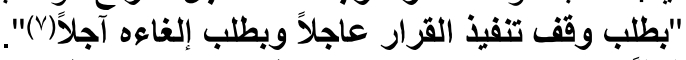

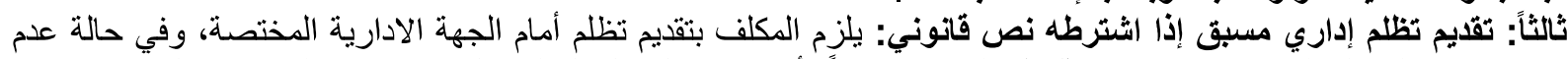

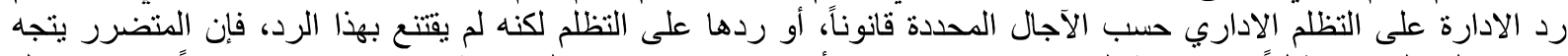

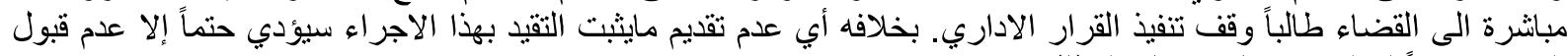

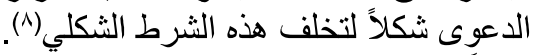

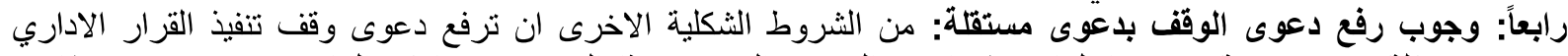

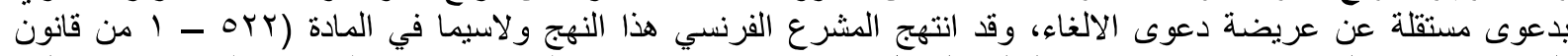

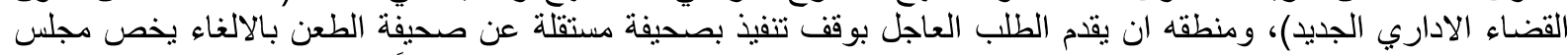

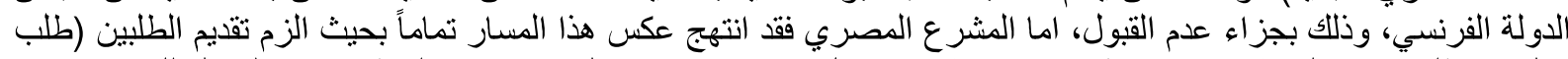

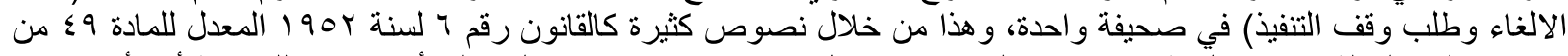

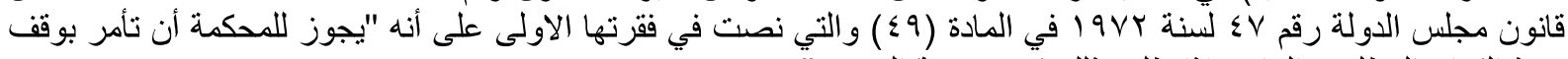

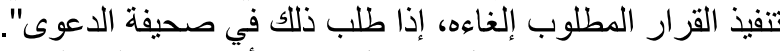

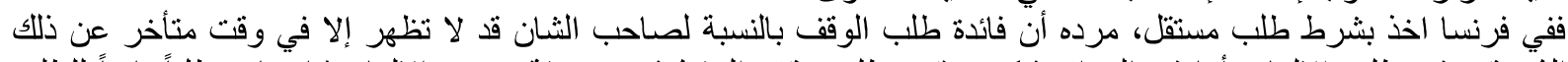

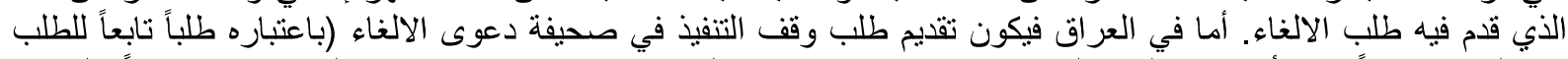

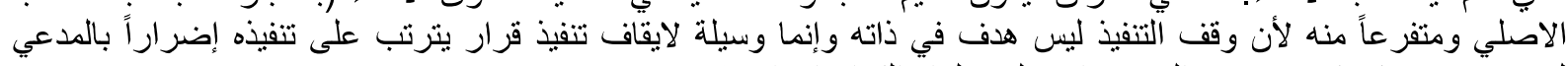

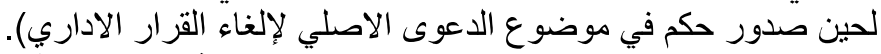

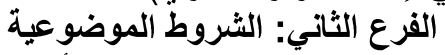

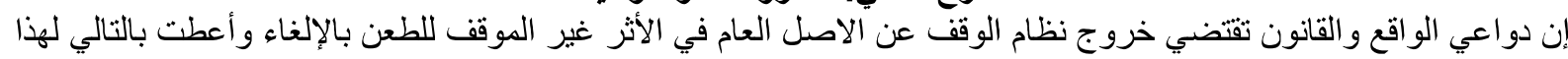

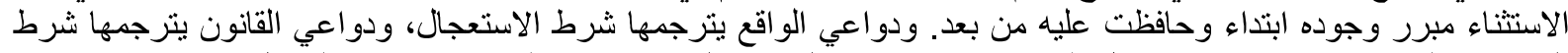

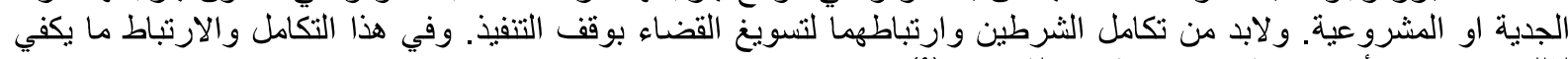

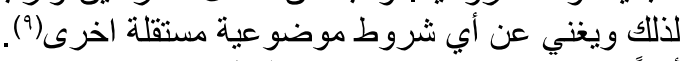

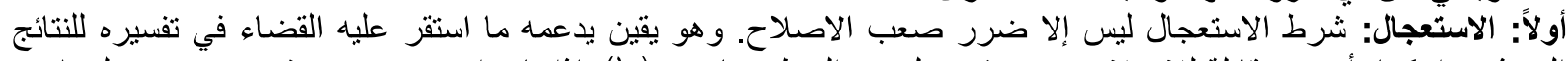

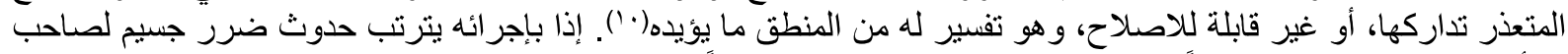

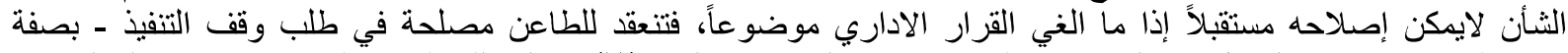

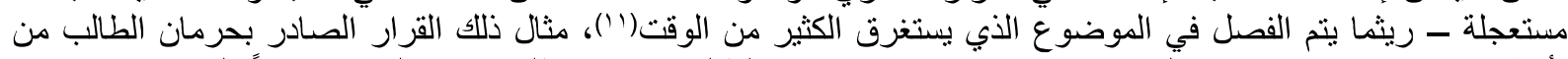

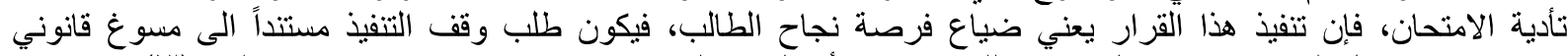

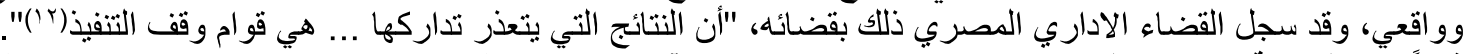

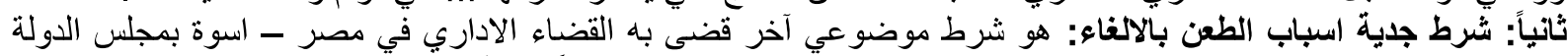

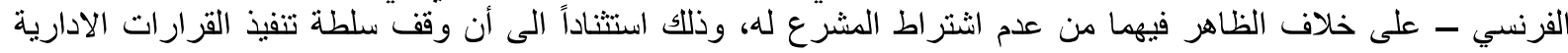

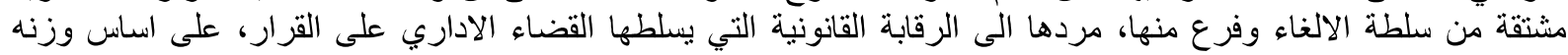

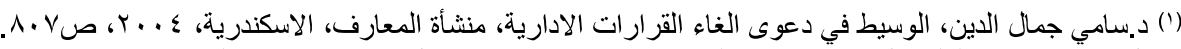

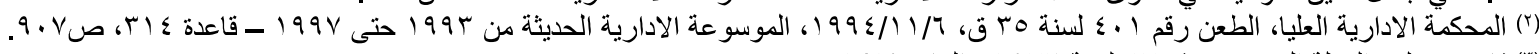

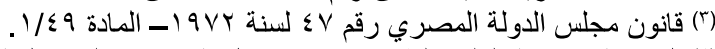

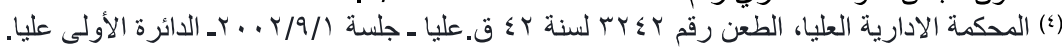

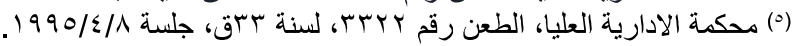

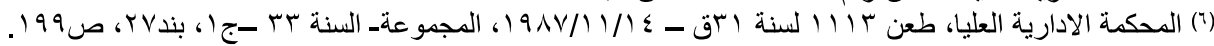

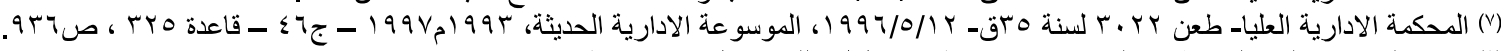

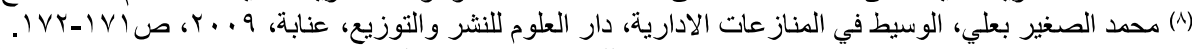

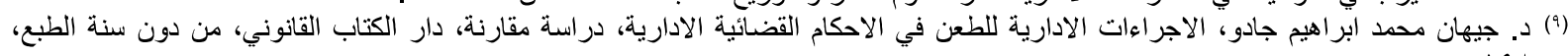

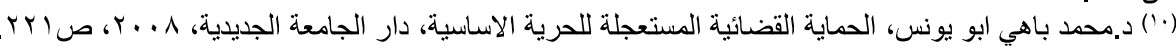

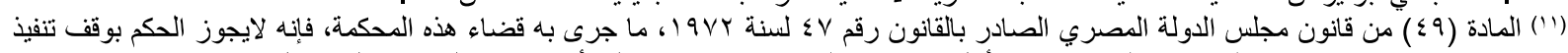

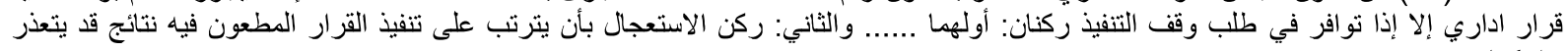

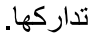

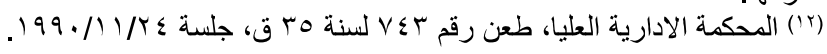




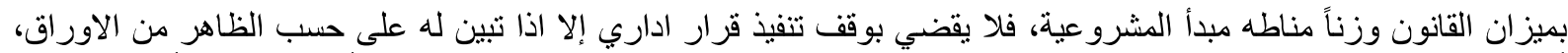

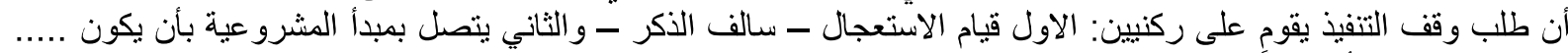

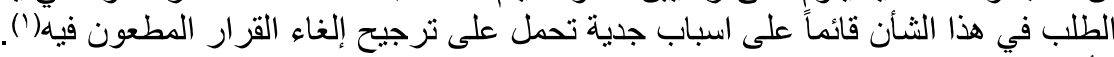

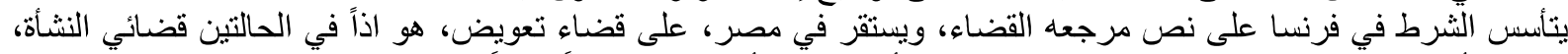

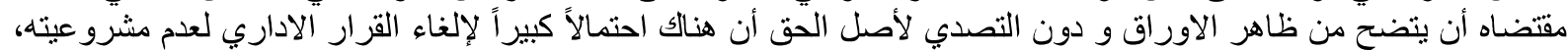

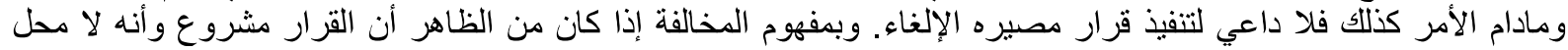

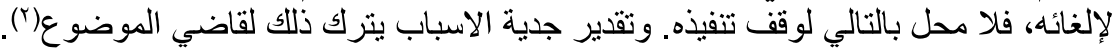

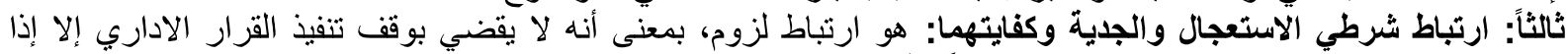

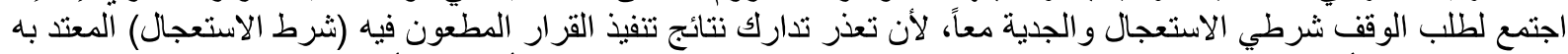

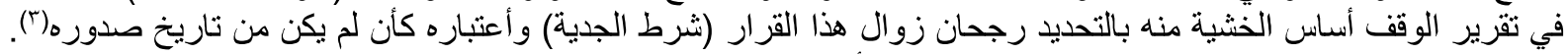

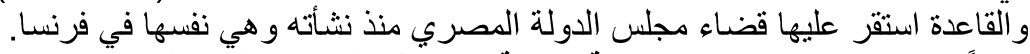

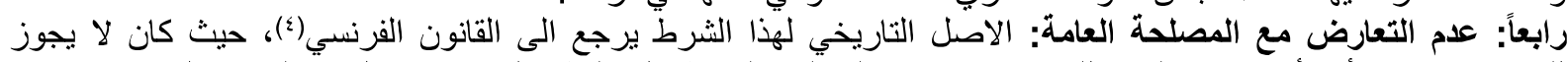

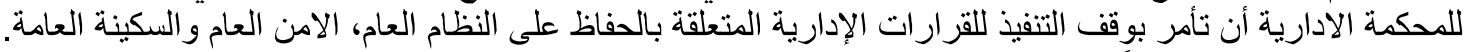

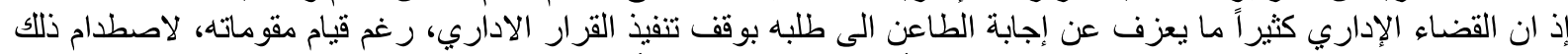

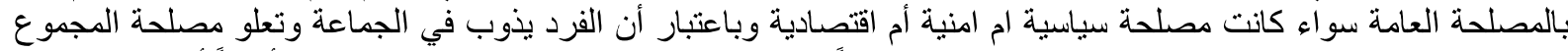

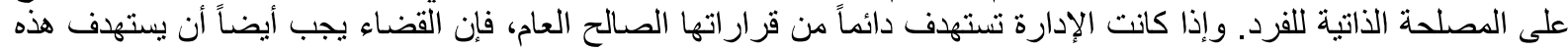

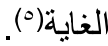

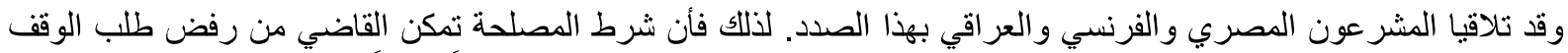

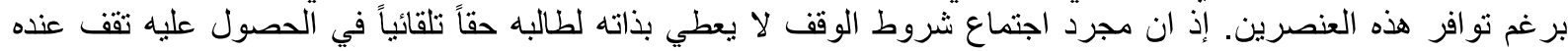

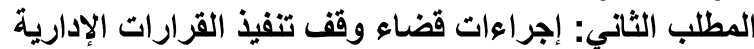

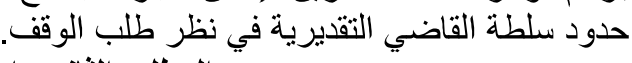

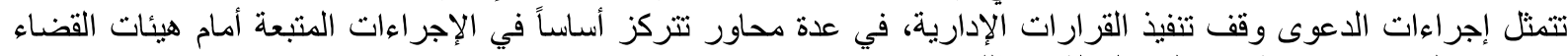

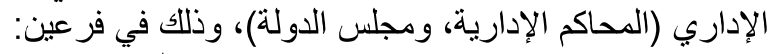

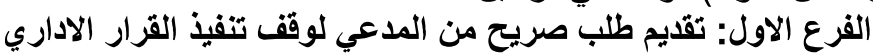

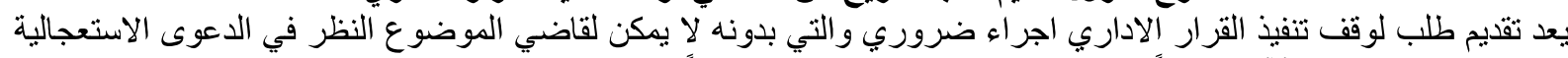

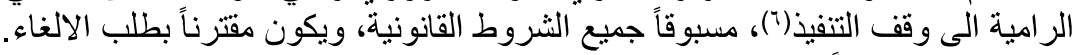

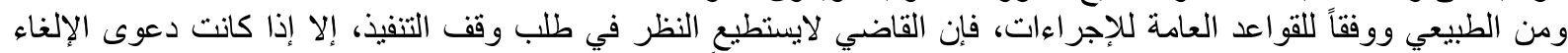

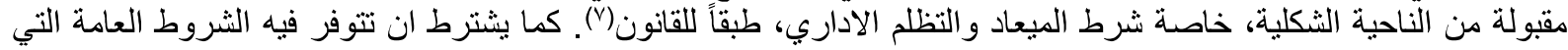

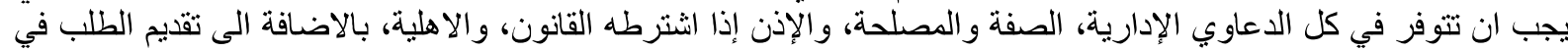

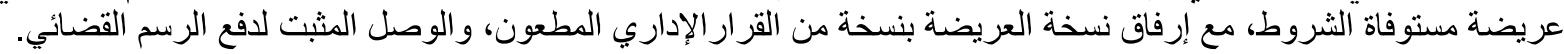

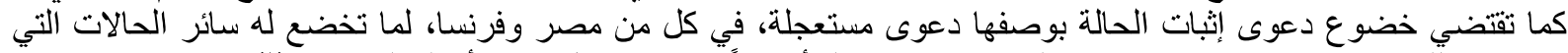

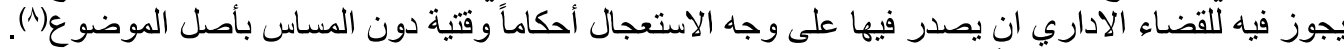

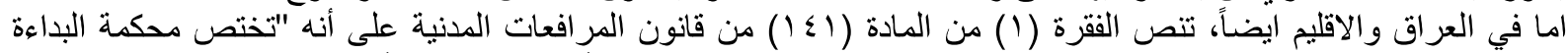

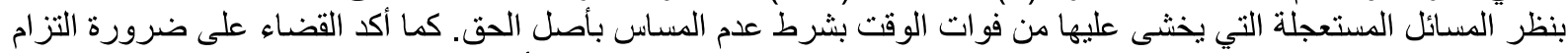

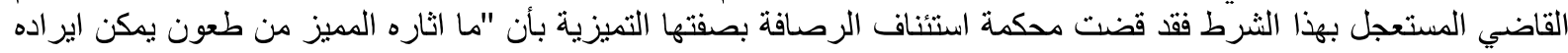

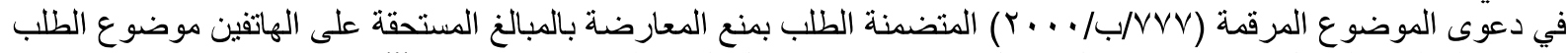
وهو اصل الحق المطالب به وحيث ال القرار المميز لايتصدى لاصل الحقل الحق، لذا قرر تصديقهة... (9)".

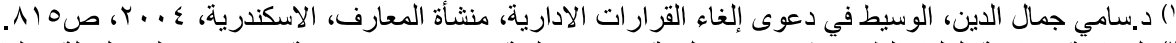

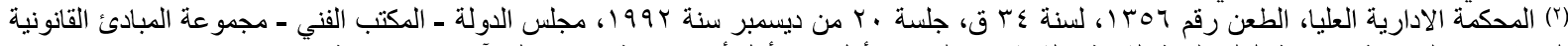

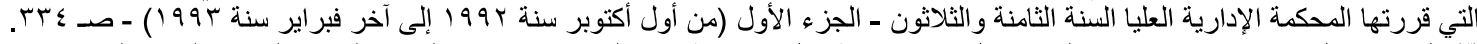

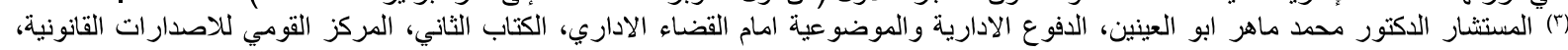

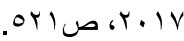

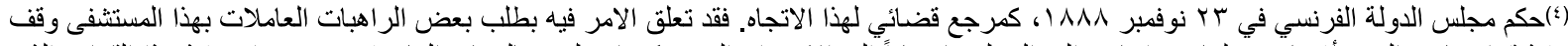

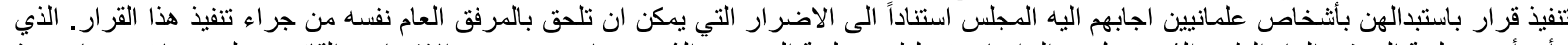

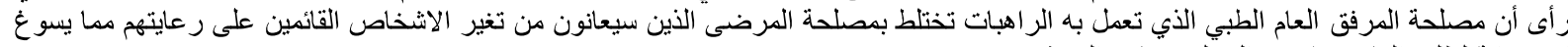

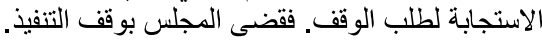

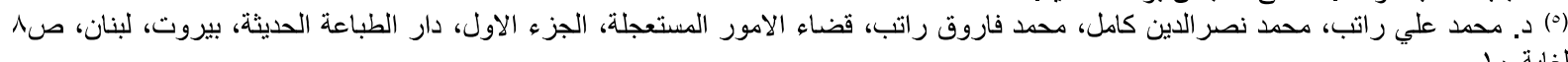

لغاية · 1.

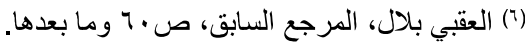

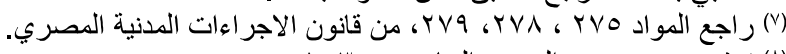

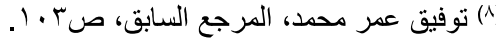

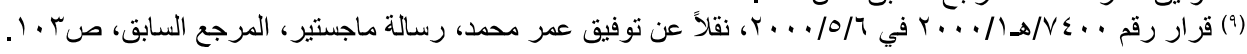


الفرع الثاني: الحكم الصادر في طلب وقف تنفيذ القرار الاداري

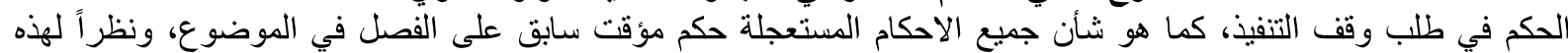

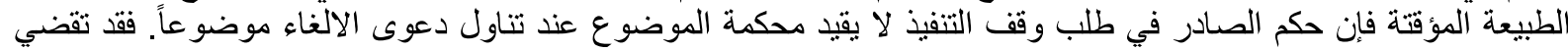

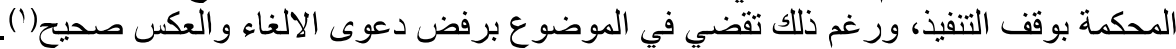

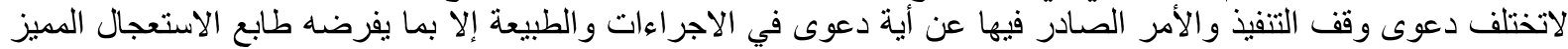

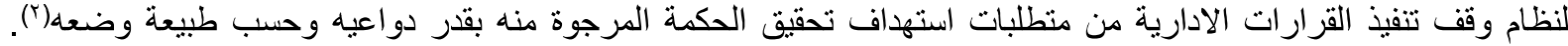

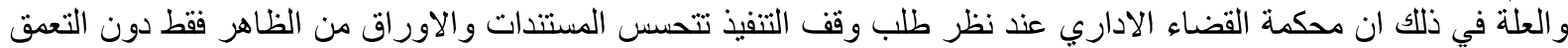

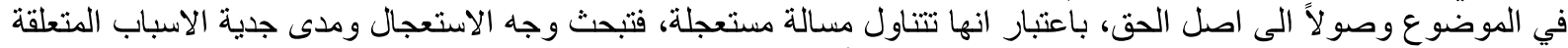

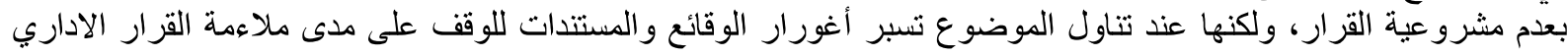

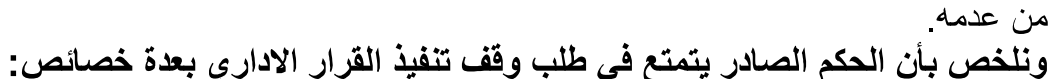

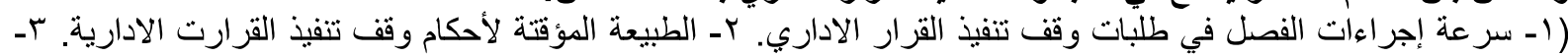

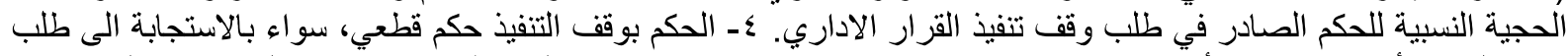

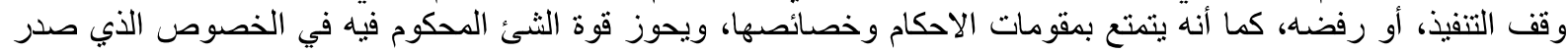

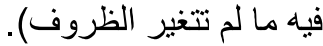

\section{الفصل الثاني \\ طبيعة قضاء وقف تنفيذ القرارت الادارية}

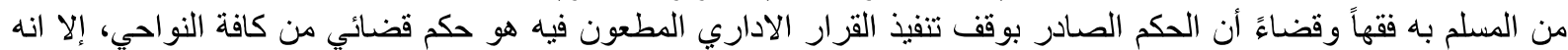

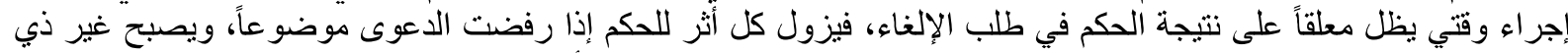

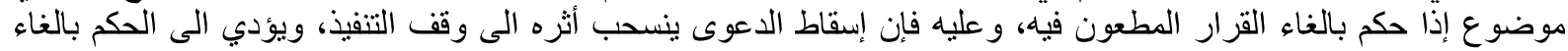

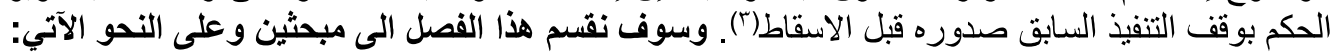

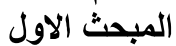

حجية الحكم الصادر بوقف التفقيذ وطرق الطب الطعن فيه

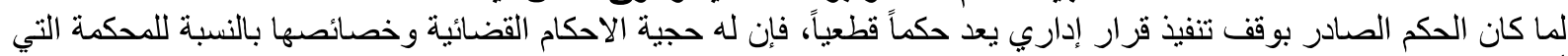

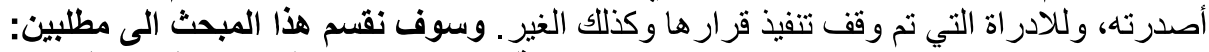

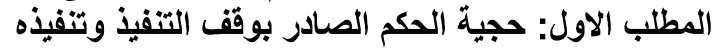

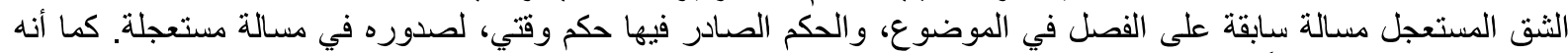
حكم قطعي، لفصله فصلاً قطعية في مسالة مطروحة على المحكمة (؛). وسوف نقسم هذا المطلب الى فرعين وعلى وعلى النحو الآتي: الفرع الاول: حجية الحكم الصادر بوقفة الإنف التنفيذ

ان للحكم الصادر بوقف تنفيذ القرار الاداري، مقومات الاحكام القضائية وخصائصها ويترتب عليها ثثار بالنسبة للحككة مصدرة

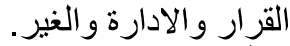

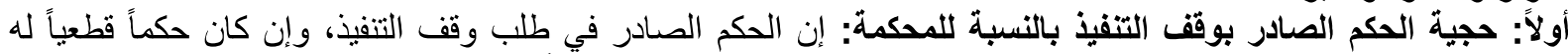

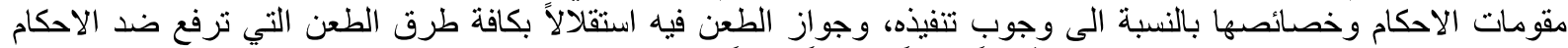

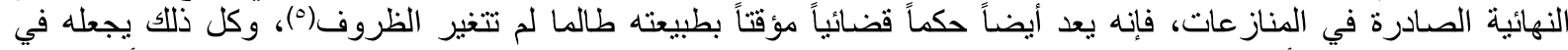

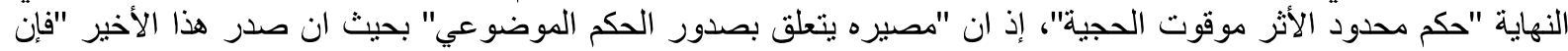

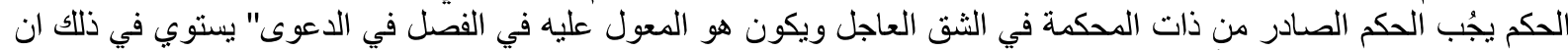

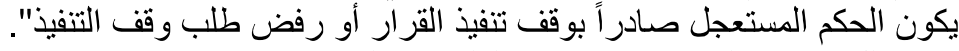

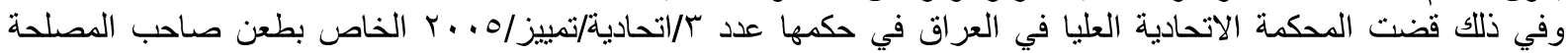

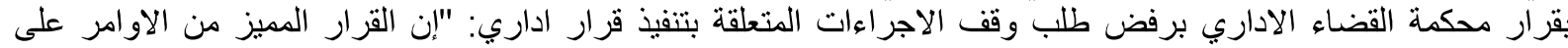

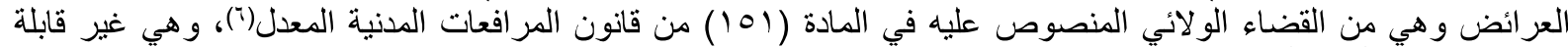

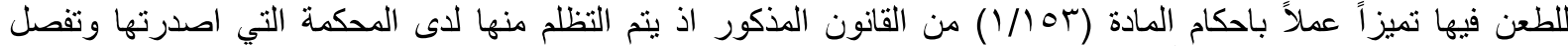

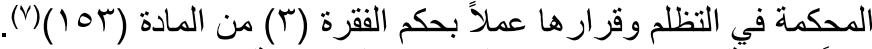

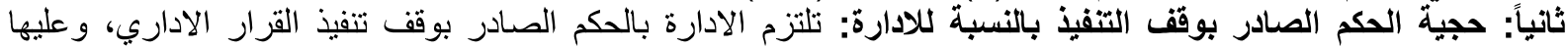
الامتناع عن تنفيذ هذا القرار إذا لم تكن قد بدأت في تنفيذه بالفعل، اما إذا كانت قد بدأت في تنفيذه فيجب عليها التها التوقف عن

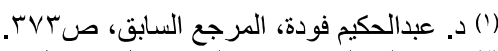

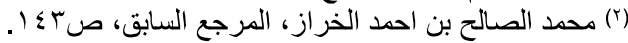

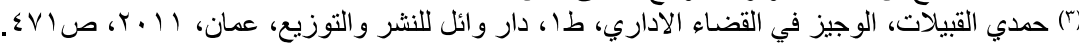

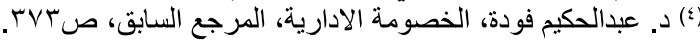

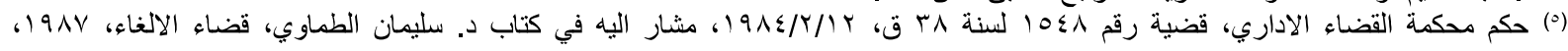

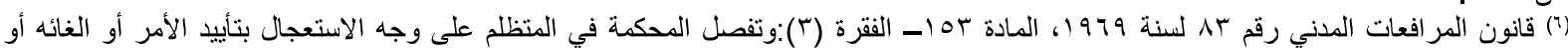

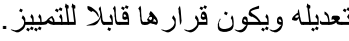

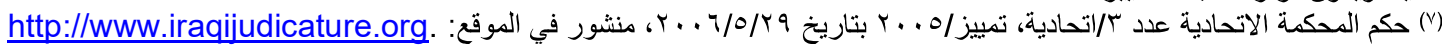


استكمال هذا التنفيذ، كما يجب عليها من ناحية أخرى عدم إصدرا قرارات ادارية أخرى استناداً الى القرار الذي قضي بوقف تنفيذه.

ولقد أوضحت محكمة القضاء الاداري المصري هذا المعنى حيث قضت بان بان: "الحكم بوقف تنفيذ القرار الاداري معناه أن يعود الإد

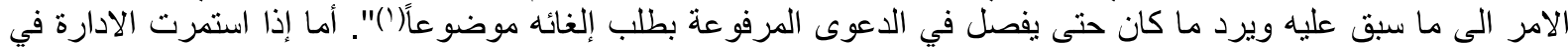

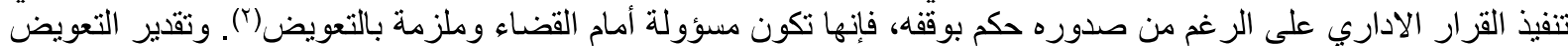
المترتب في هذه الحالة، فإن أحكام القضاء الإداري في فرنسا ومصر التئ تتوسع في تقدير التعويض المستحق عن عدم تنفيذ الاحكام،

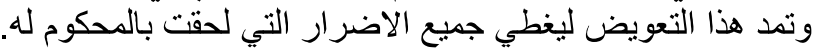

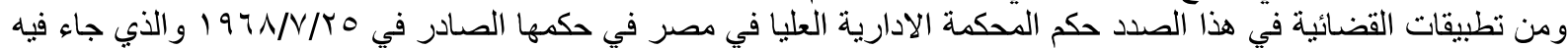

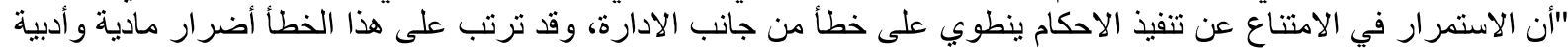

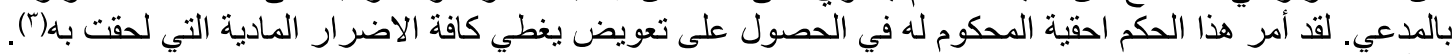

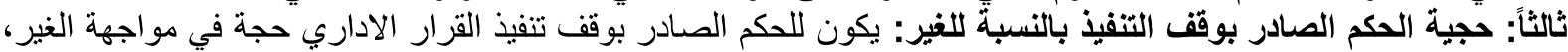

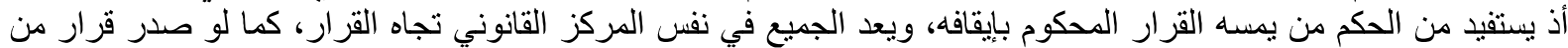

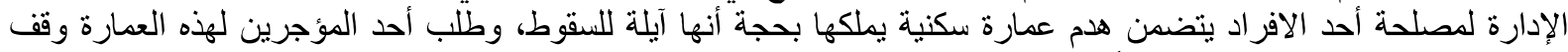

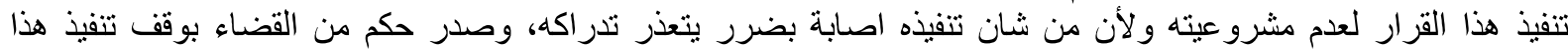

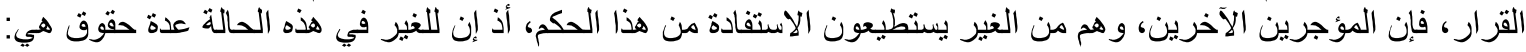

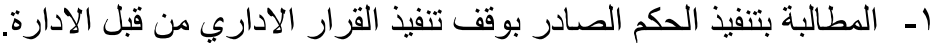

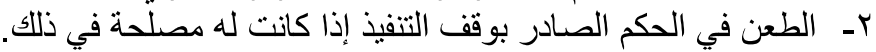

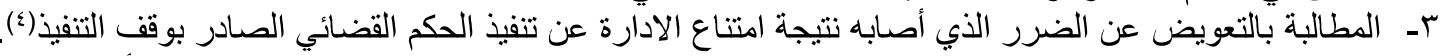

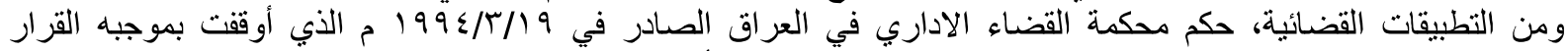

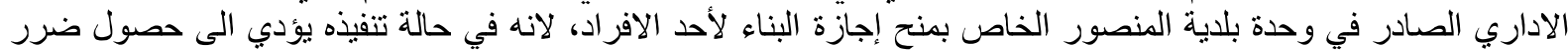

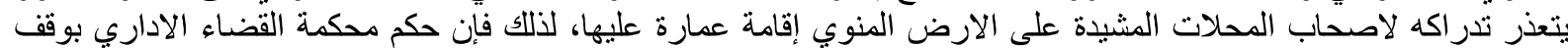

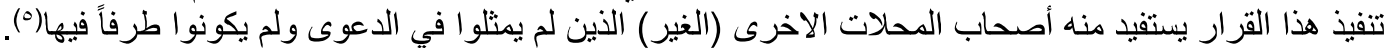

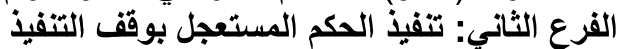

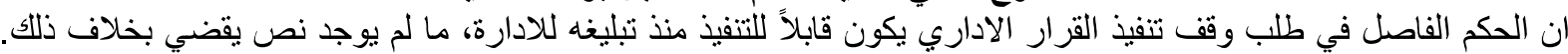

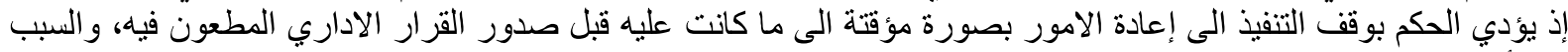

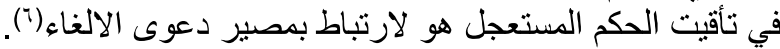

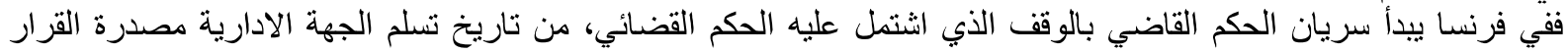

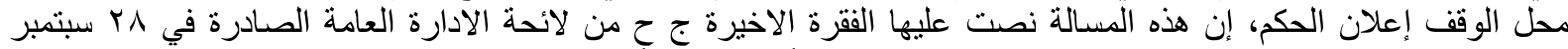

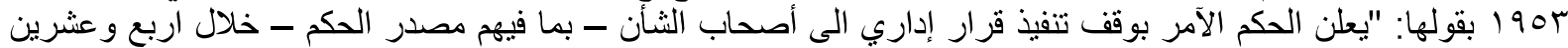

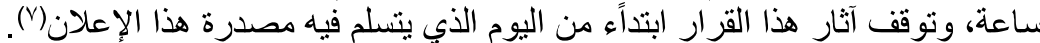

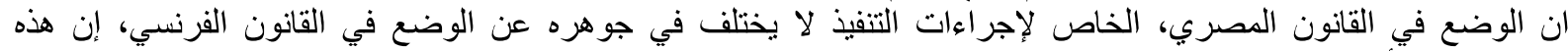

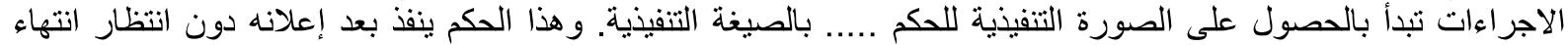

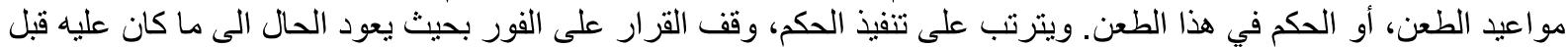

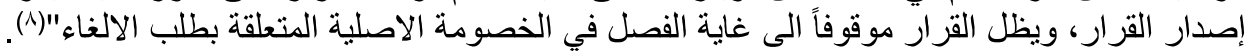

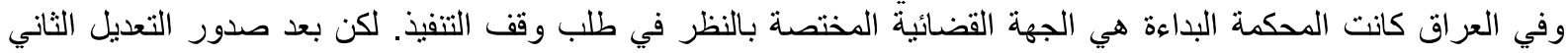
لقانون مجلس شورى الدولة بالقانون رقم 1 ـ 1 لسنة 19191 اصبحت محكمة القضاء الاداري هي الجهة القضائية المختصة بوقف التنفيذ بصفة مؤقتة. وقد يكون الحكم بوقف التتفيذ غير ذي جدوى من الناحية العلمية، لأن الغاية من المطالبة بالإلغاء قد يتوصل اليها الطاءلة الطاعن

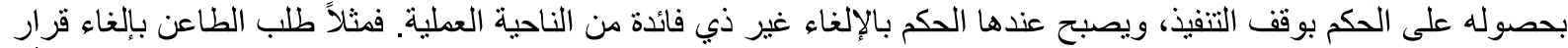

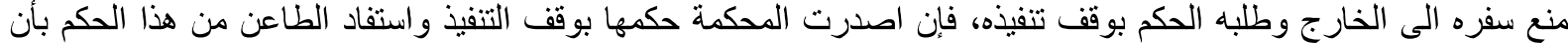

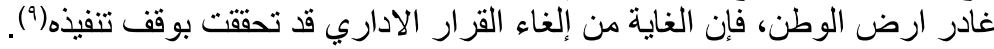

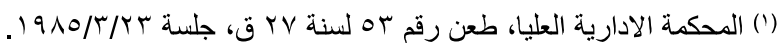

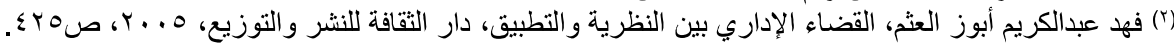

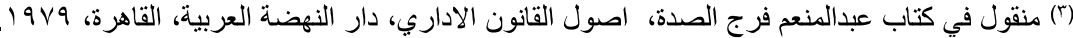

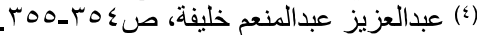

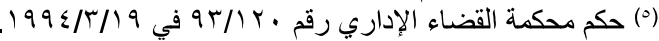

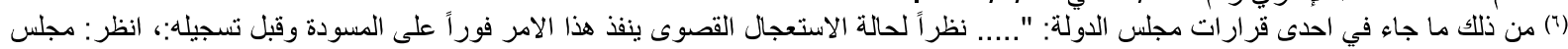

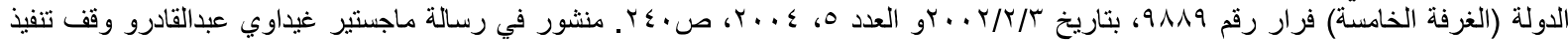

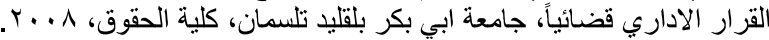

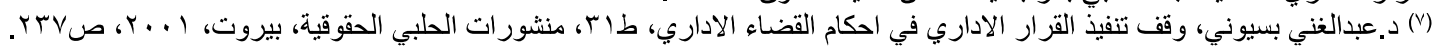

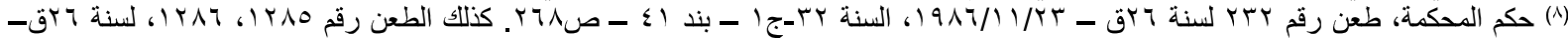

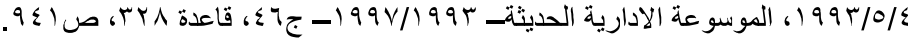

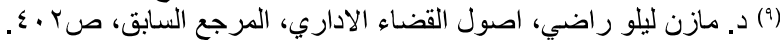




\section{المطلب الثاني: طرق الطعن في الحكم الصادر بوقف تنفيذ القرار الإداري}

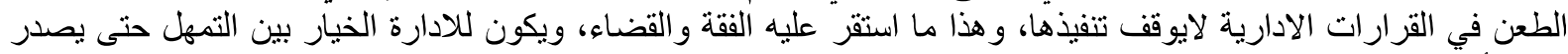

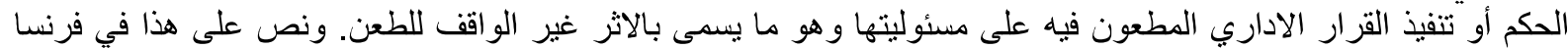

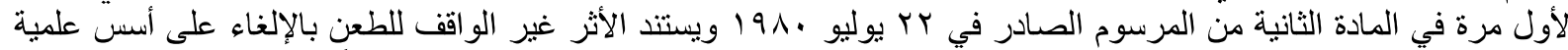

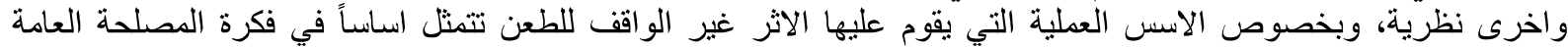

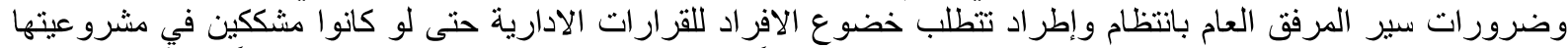

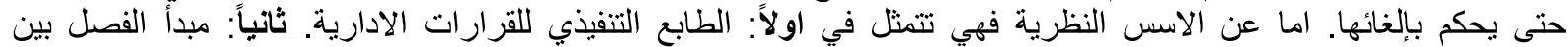

السلطات

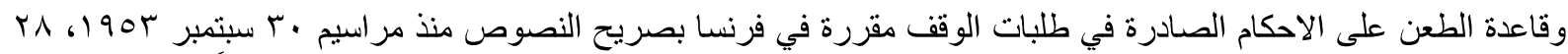

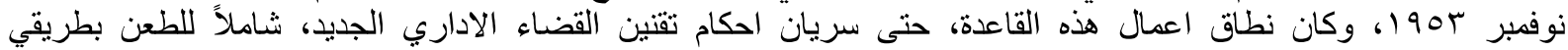

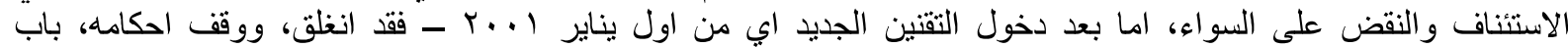

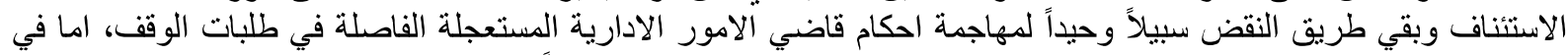

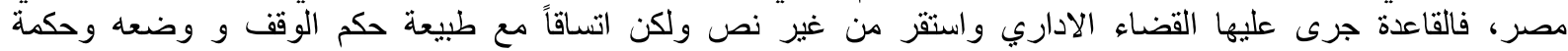

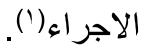

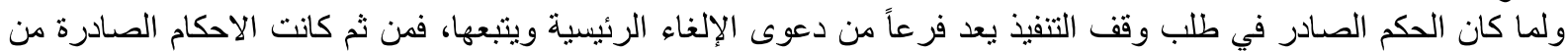

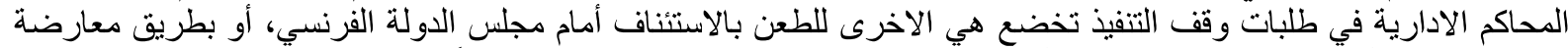

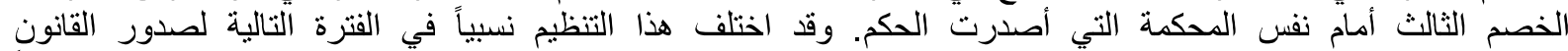

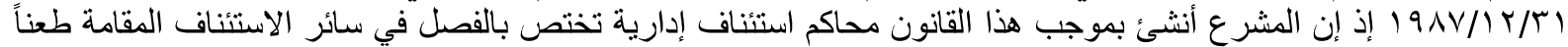
في الاحكام الصادرة من المحاكم الادارية في أول درجة، وقد أجاز ذات القان القانون الطعن في الاحكام الصادرة من محاكم الاستئناف

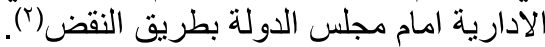

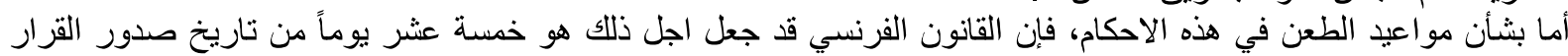

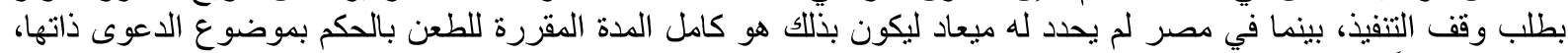

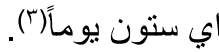

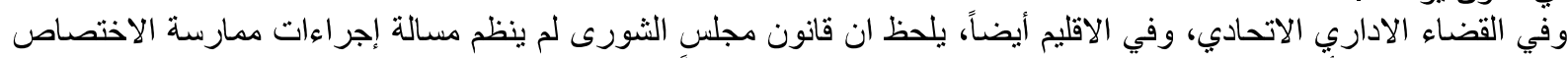

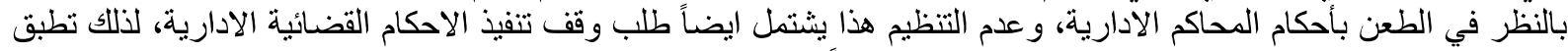
القو اعد العامة للطعن في الاحكام الصادرة الإدارية عن القضاء عموماً.

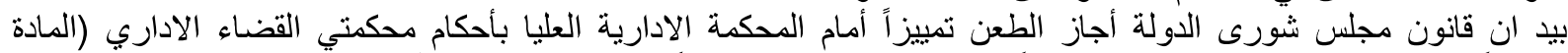

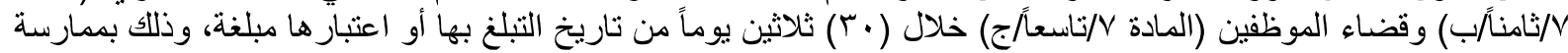

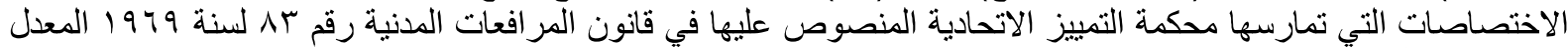

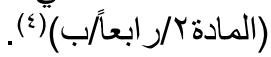

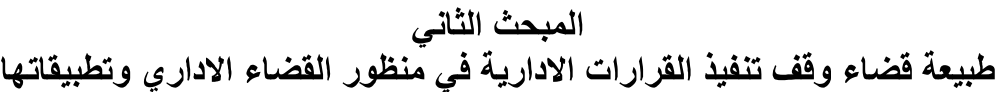

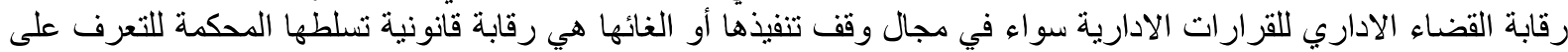

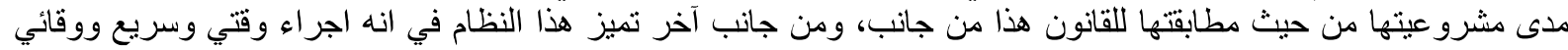

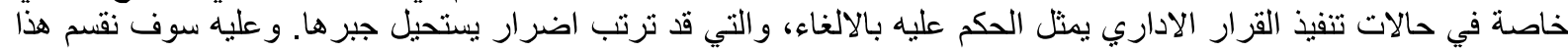

المطلب الاول: طبيعة قضاء وقف تنفيذ القرارات الادارية في القضائين الاداريين الفرنسي والمصري المبحث الَى مطلبين:

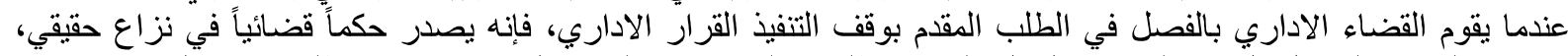

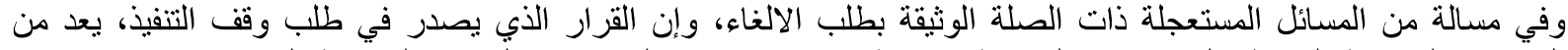

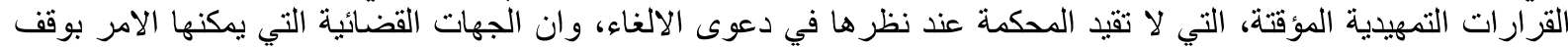

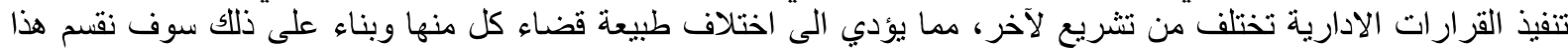

\section{الفرع الاول: القضاء الاداري الفرنسي}

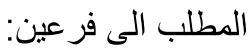

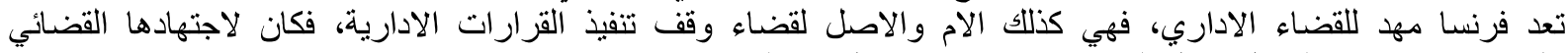

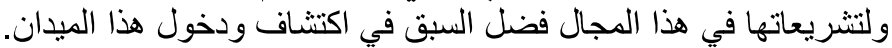

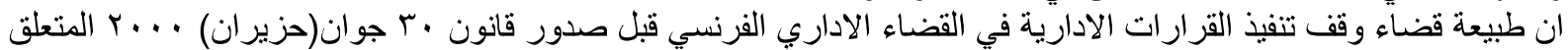
بالقضاء المستعل، كان يتم إما بأمر عن مجلس الدولة أو بأمر عن المحاكم الادارية، بناء على طلب طبل صريح من الطاعن ويعتقد

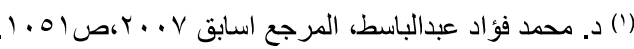

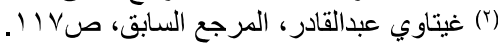

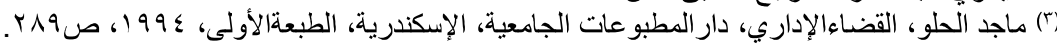

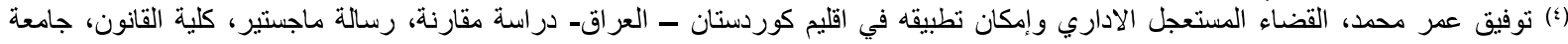




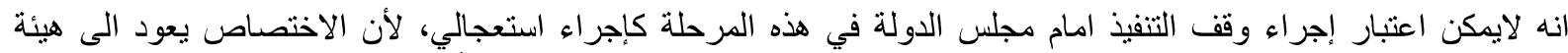

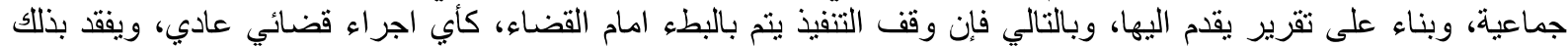

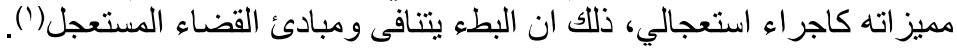

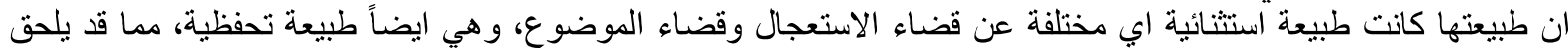

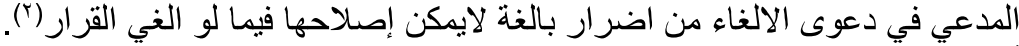

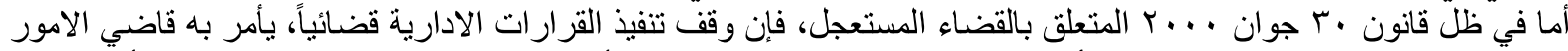
المستعجلة وقد تحدد بقاضي فرد وهو أما ان يكون رئيس المحكمة الادارية أو رئيس محكمة الاستئناف الادارية، أماً بالنسبة الأنية

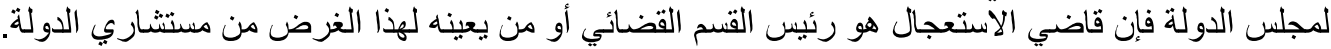

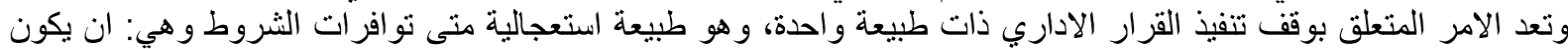

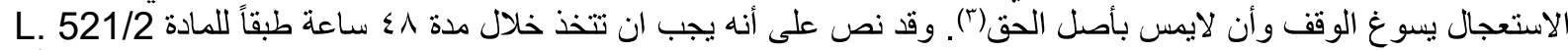

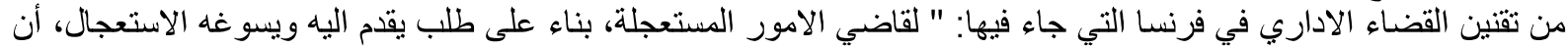

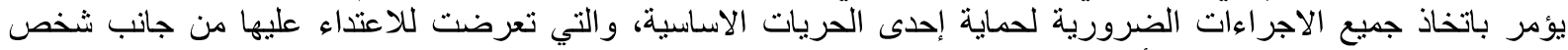

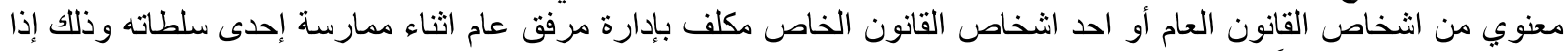

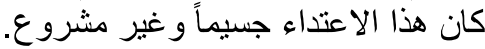

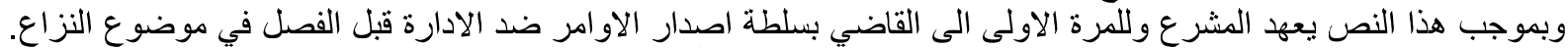

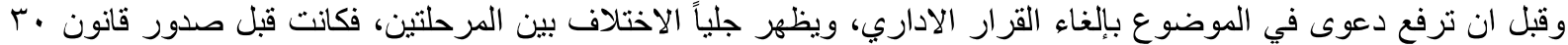

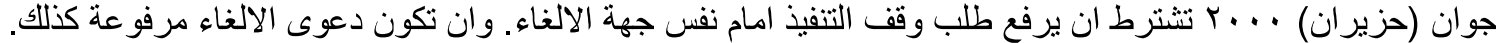

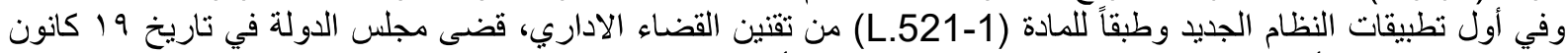

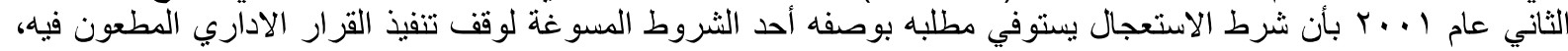

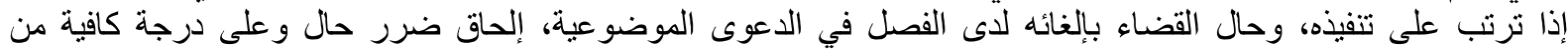

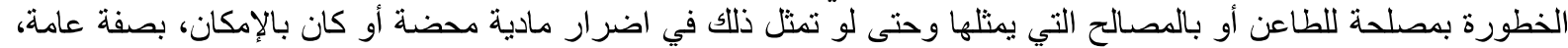

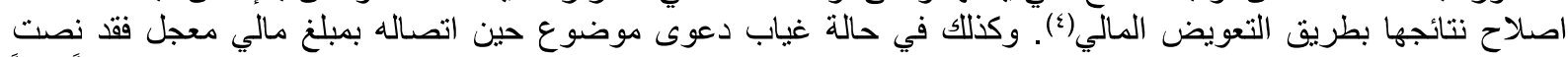

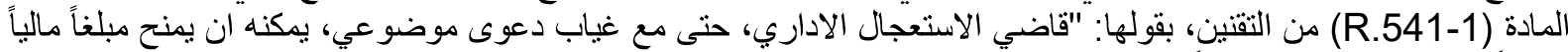

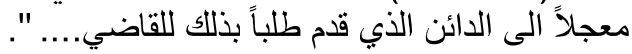

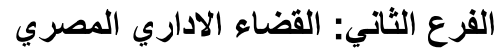

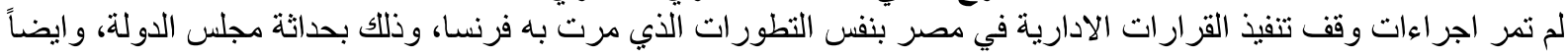

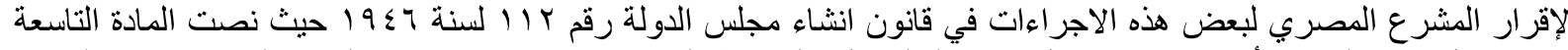

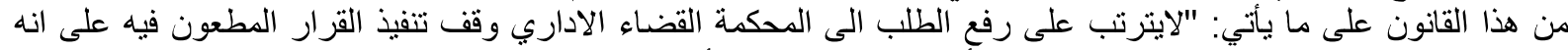

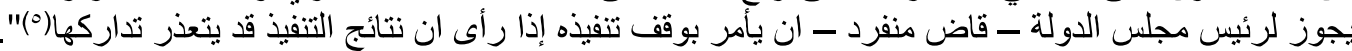

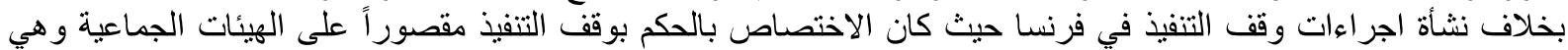

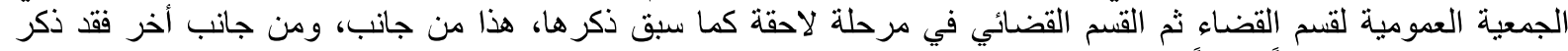

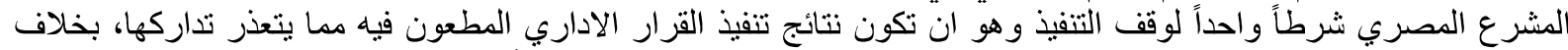
التشريع الفرنسي التي لم ينص منذ تنظيم اجر اءات وقف التنفيذ امام مجلس الدولة على أية شروط للحكم بوقف التنفيذ وترك الته تقدير ظروف الوقف لَّجلس الدولة.

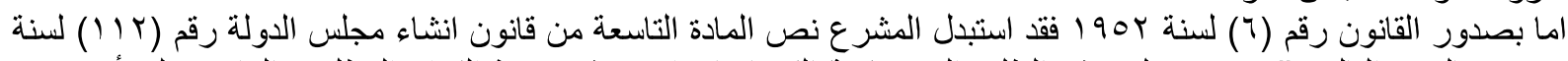

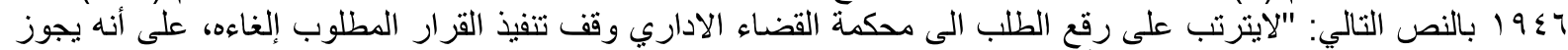

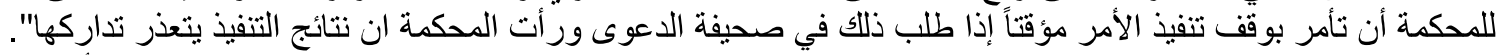

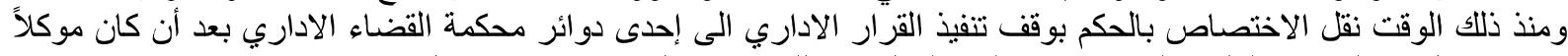

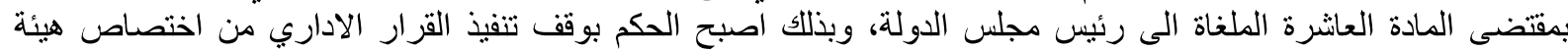

قضائية كما هو الحال في فرنسا.

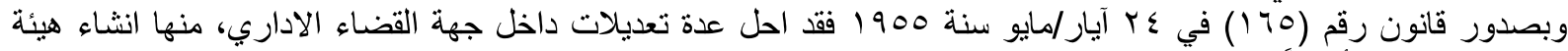

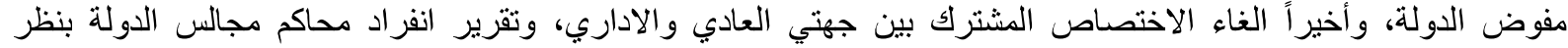

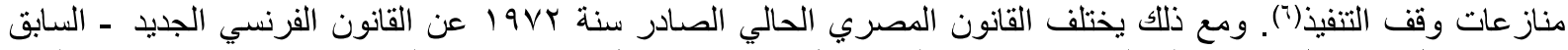
شرحه في الفرع الاول من هذا المطلب - في تحديد القاضي المختص بنظر طلبات وقف تتفيذ القرارات الادارية إذ جاء في المادة

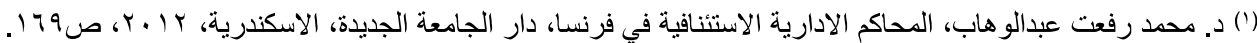

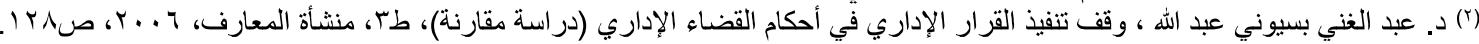

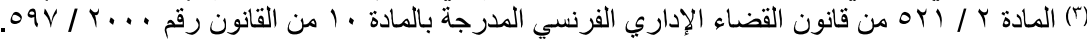

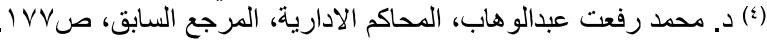

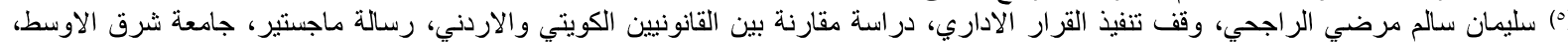




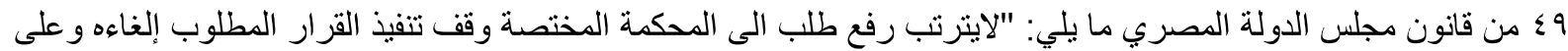

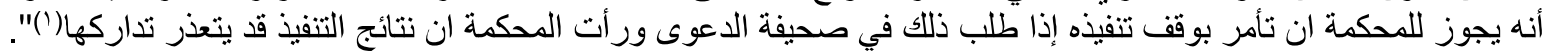

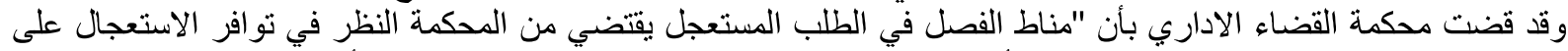

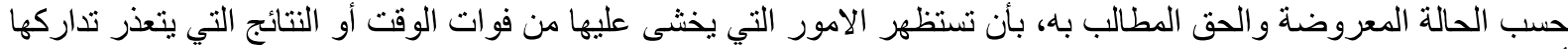

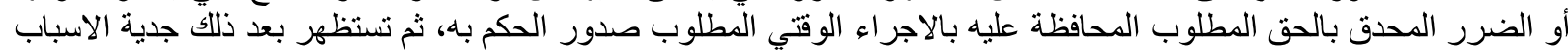

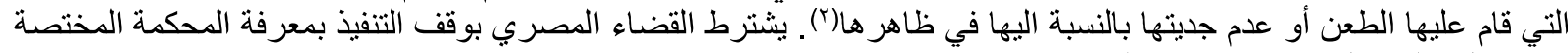
بنظر طلب إلغاء القرار الاداري ما يلي:

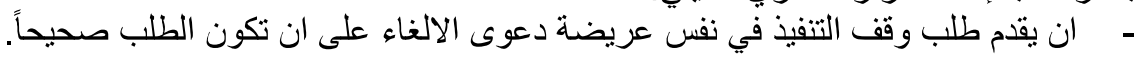

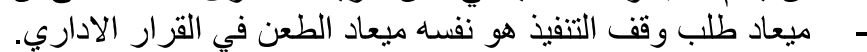

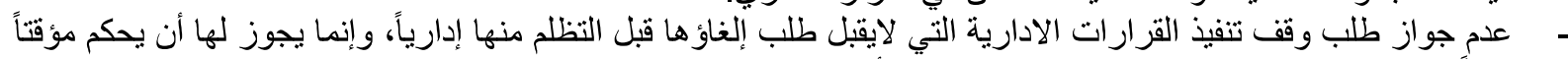

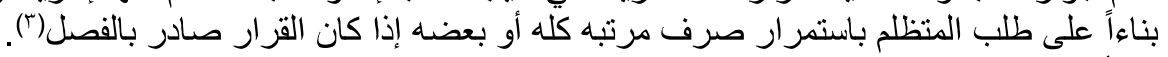

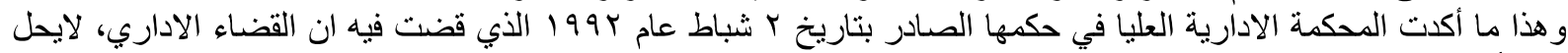

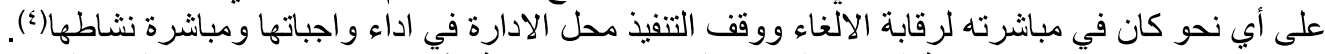

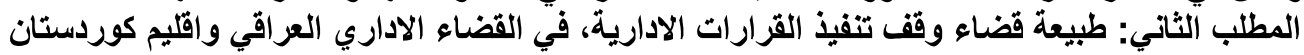

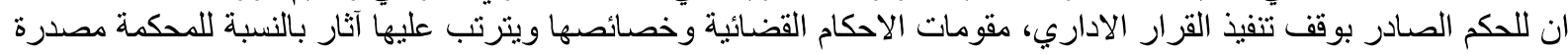

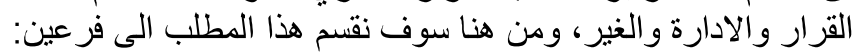

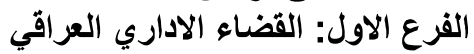

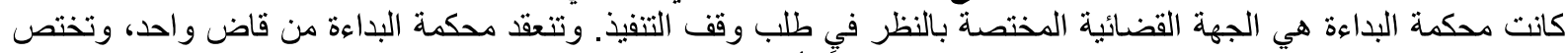

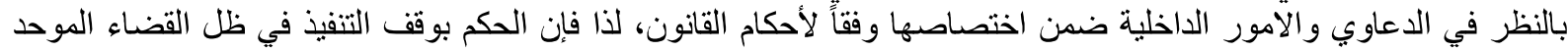

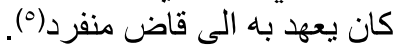

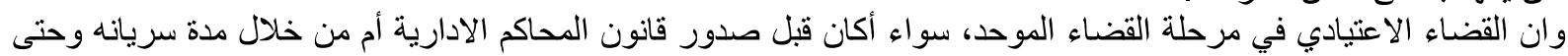

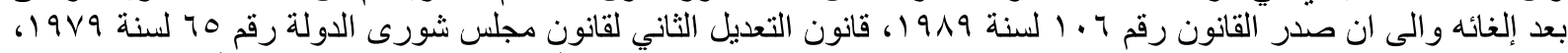

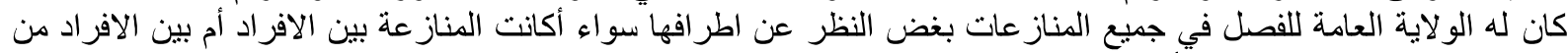

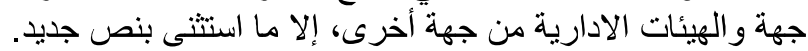

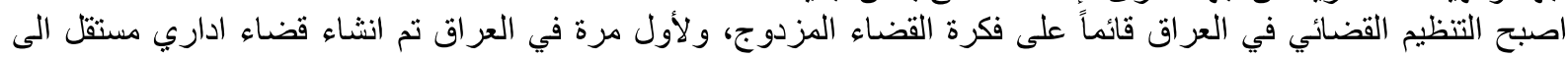

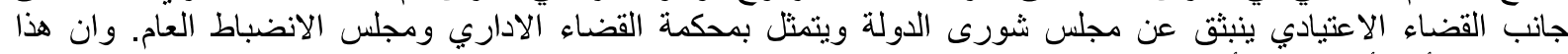

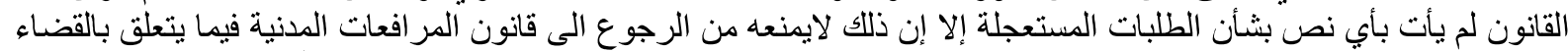

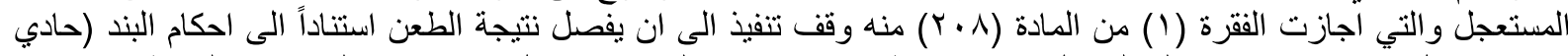

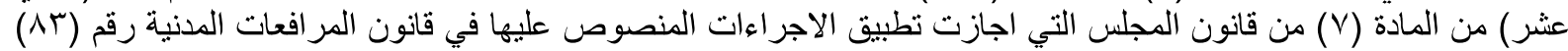

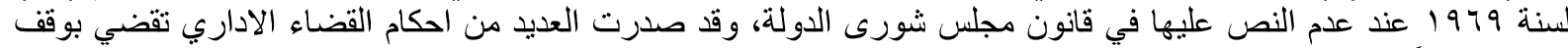

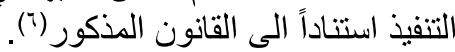

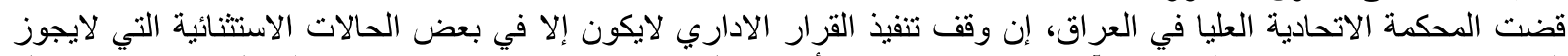

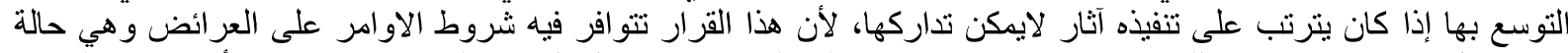

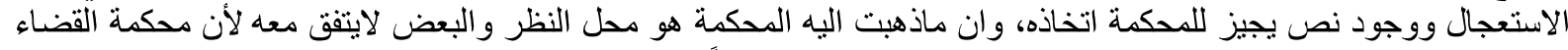

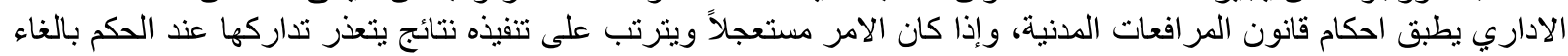

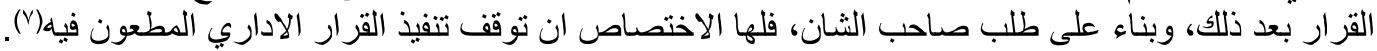

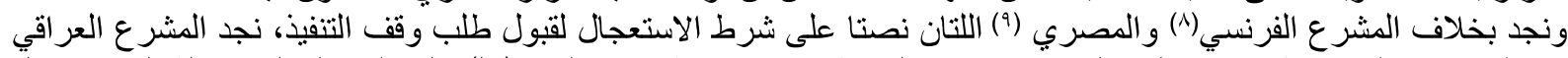

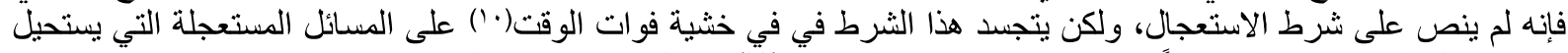

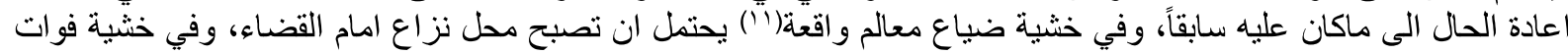

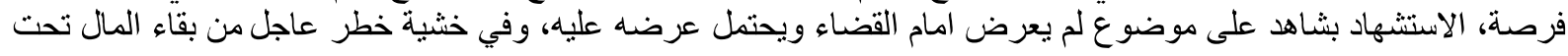

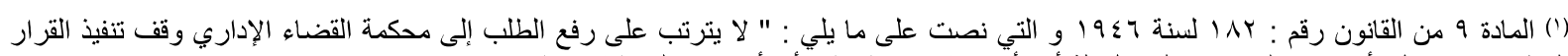

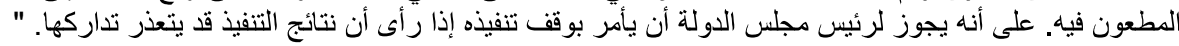

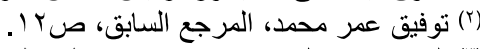

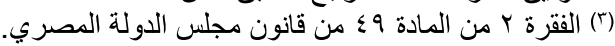

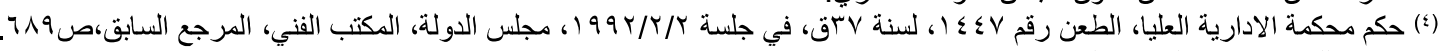

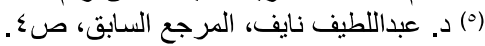

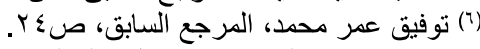

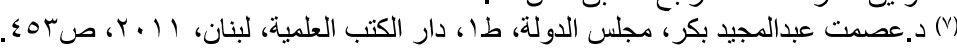

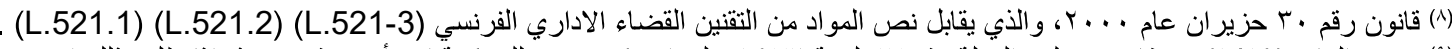

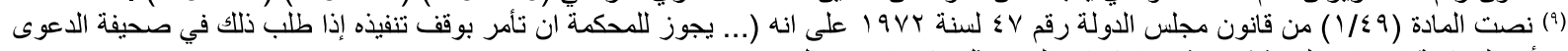

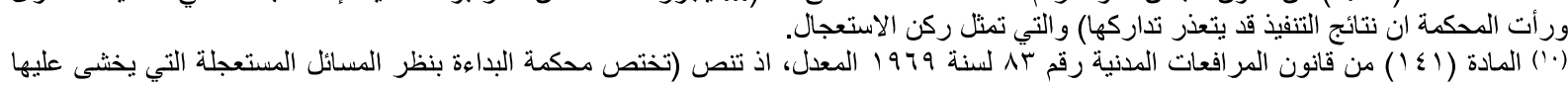

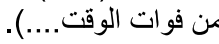

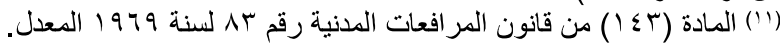




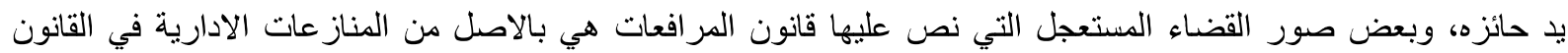

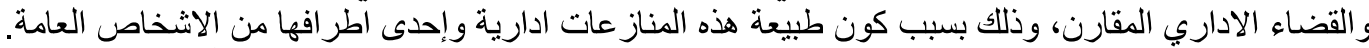

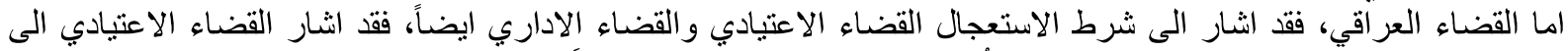

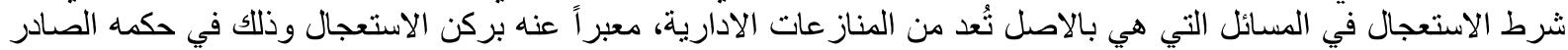

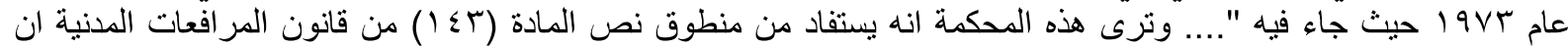

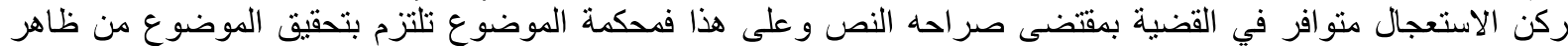

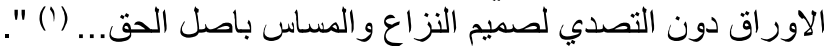

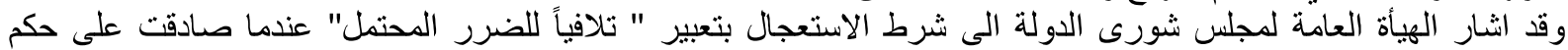

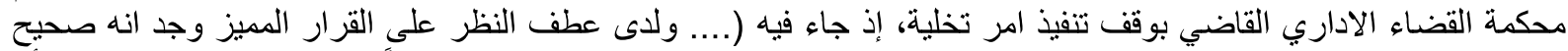

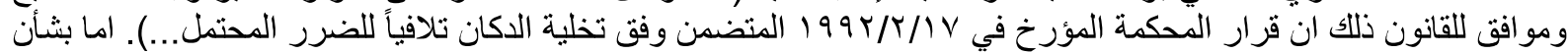

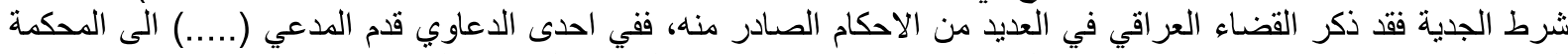

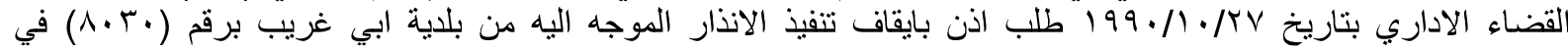

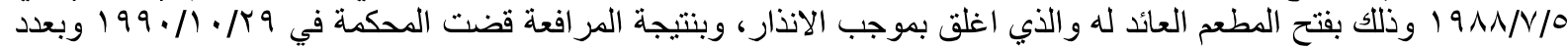

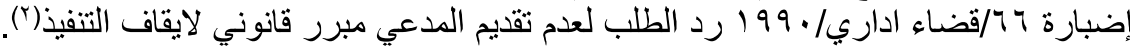

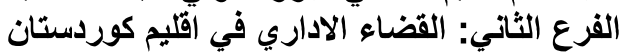

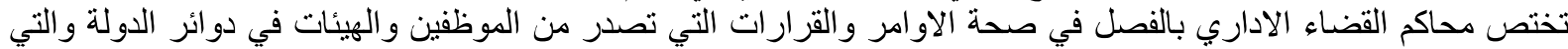

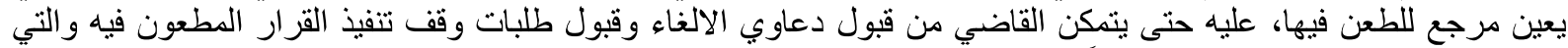

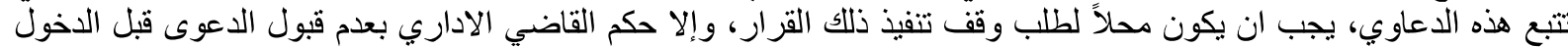

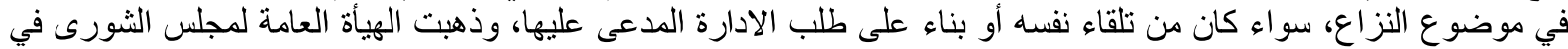

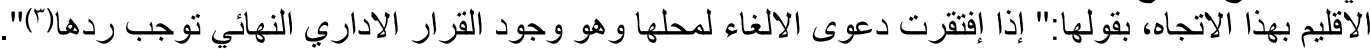

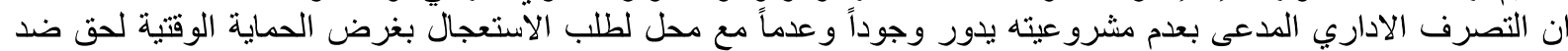

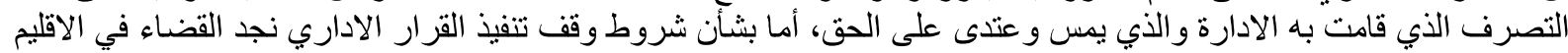

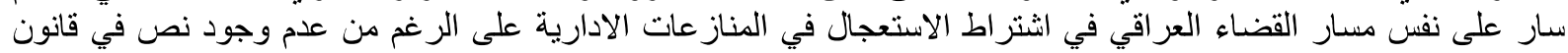

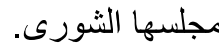

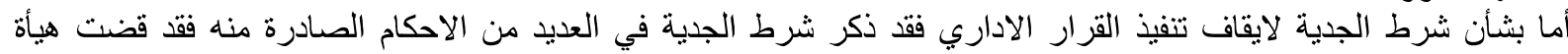

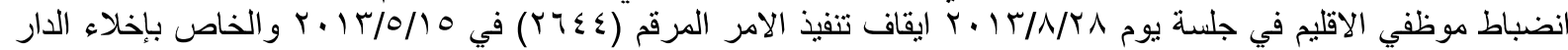

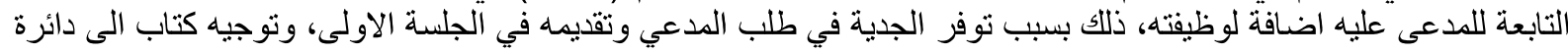
الددعي لارسال النسخ الاصلية من اوليات التحقيق وتبليغ الدائرة الدذكورة بقرار ايقاف تتفيذ الامر لحين الانتهاء من الفصل في في التهائ

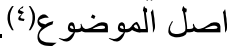

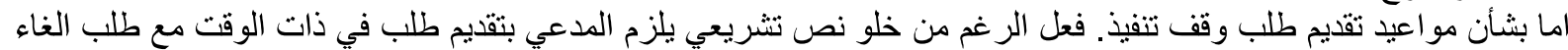

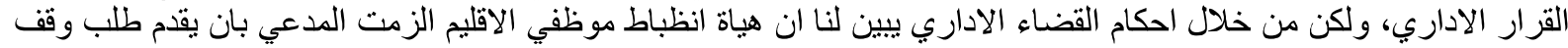

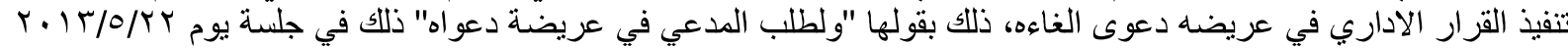

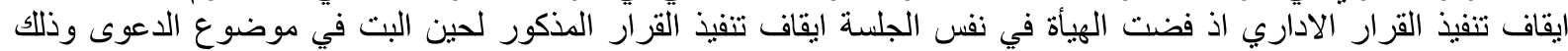

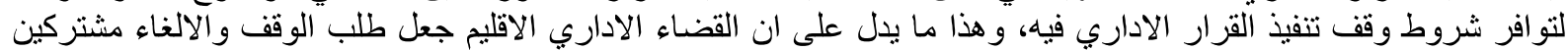

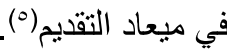

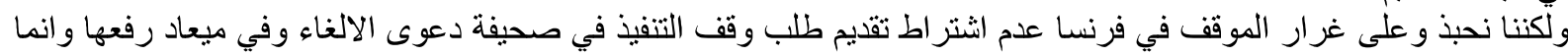

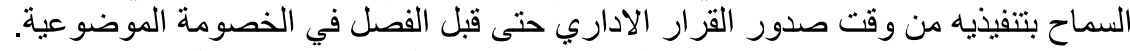

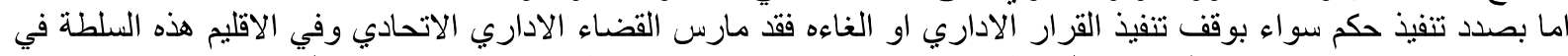

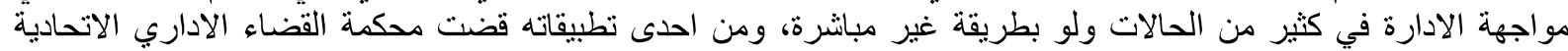

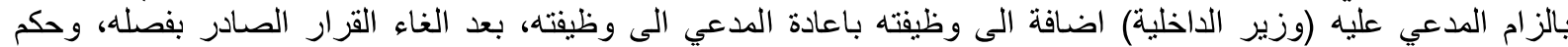

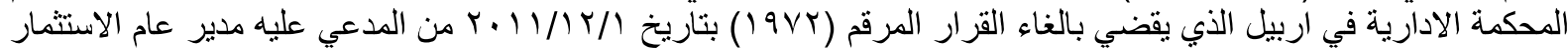

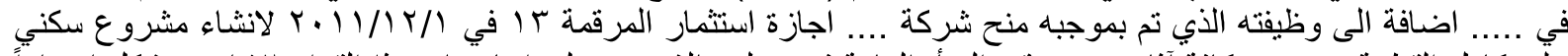

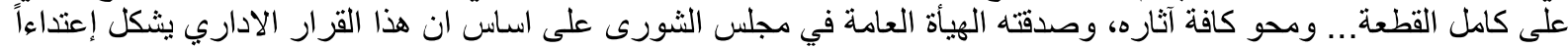

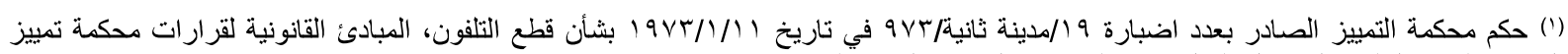

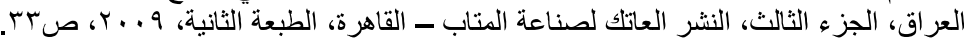

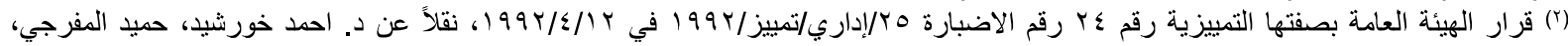

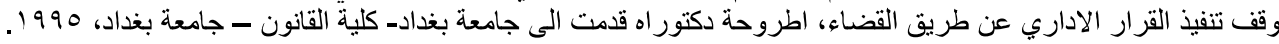

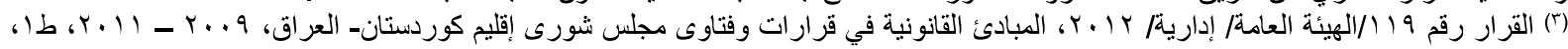

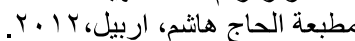

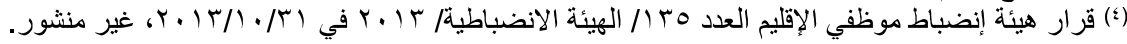

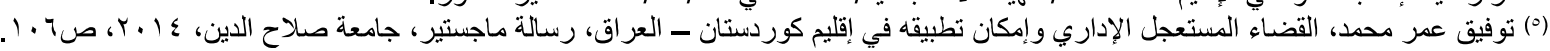


على حق ..... الفرد ومخالفة للدستور والقانون لأن دستور العراق لسنة ه. . ب كفل للملكية الخاصة صرفتها ولم يجد المساس الخاتمة

بها إلا إسنتناءً) (1)

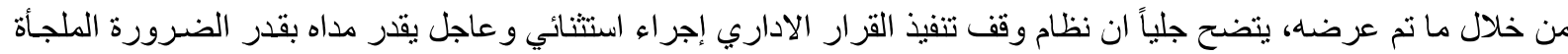

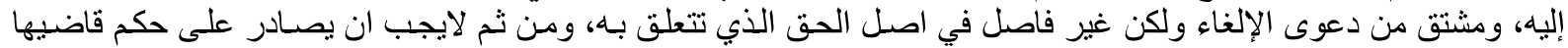

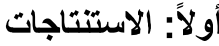

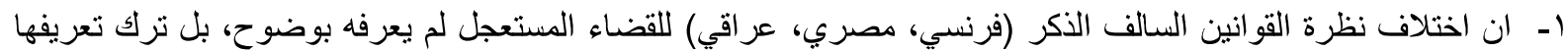

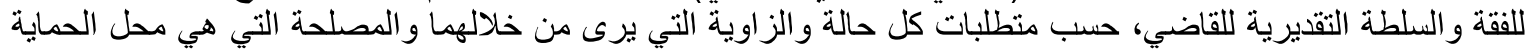
القضائية الادارية المستعجلة.

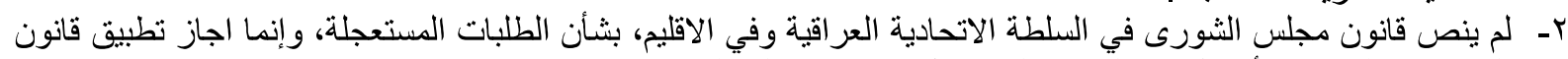

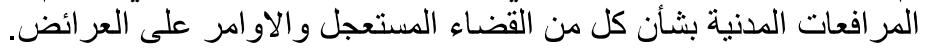

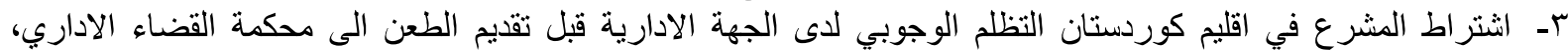

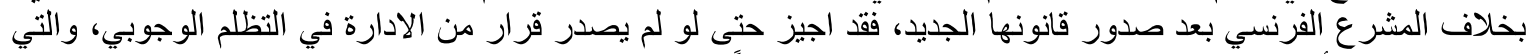

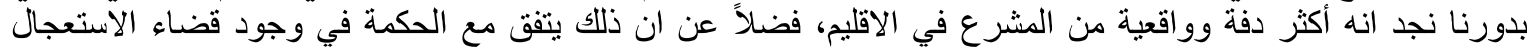
الاداري.

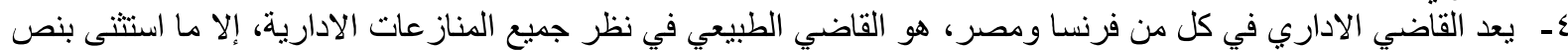

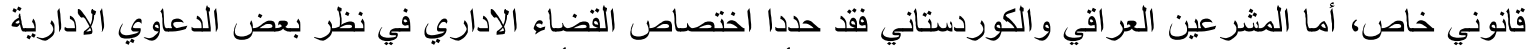

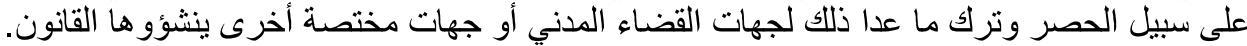

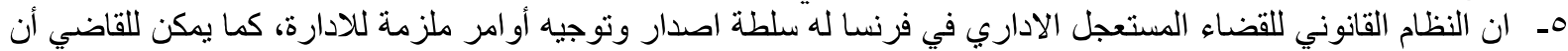

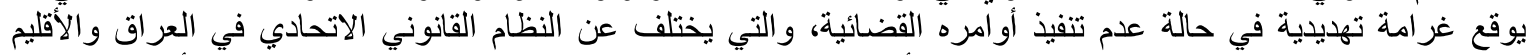

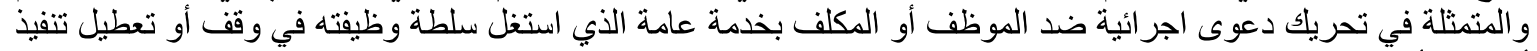

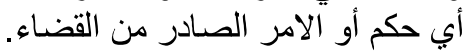

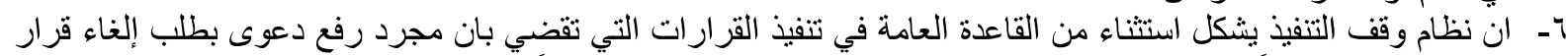

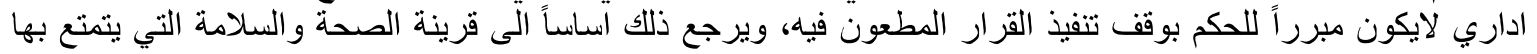
القزار الاداري.

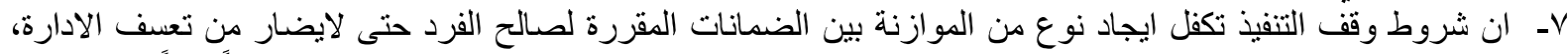

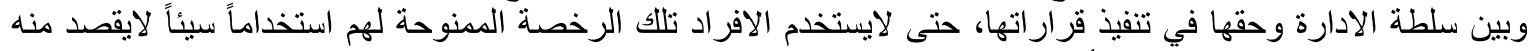

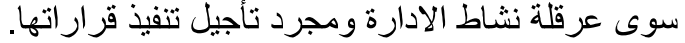

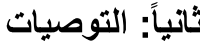

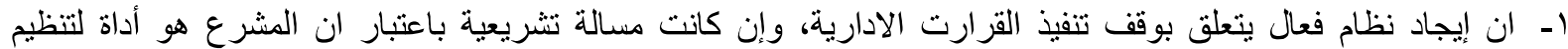

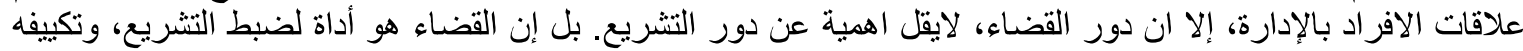

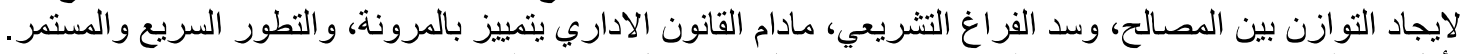

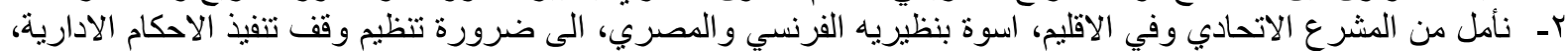

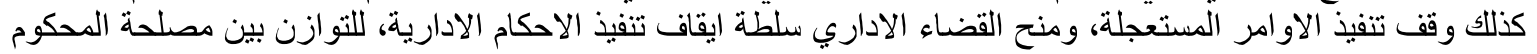

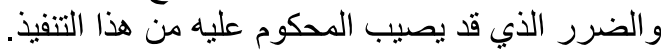

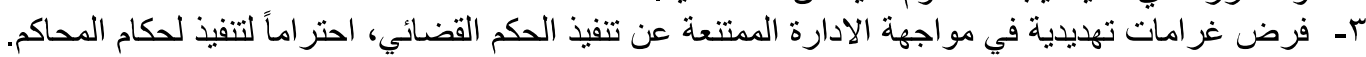

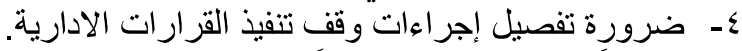

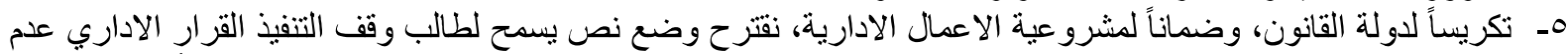

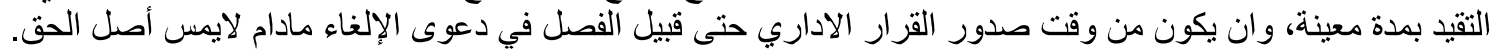

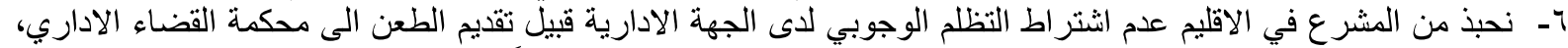

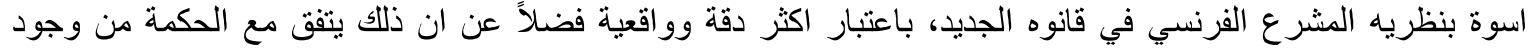
قضاء الاستعجال الاداري.

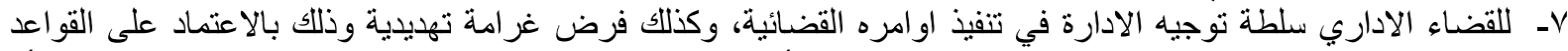

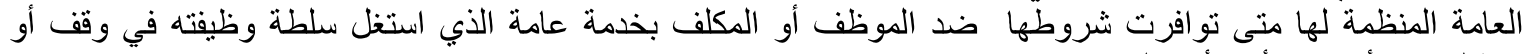

\section{قائمة المصادر} تعطيل تنفيذ أي حكم أو الأمر الصادر منه.

اولاً: الكتب • د. جيهان محمد ابراهيم جادو، الاجراءات الادارية للطعن في الاحكام القضائية الادارية، دراسة مقارنة، دار الكتاب القانوني، من دون سنة الطبع.

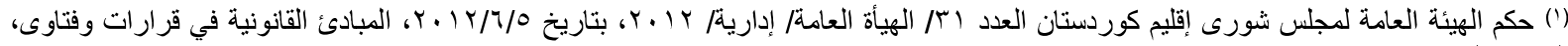

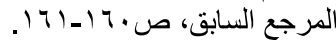




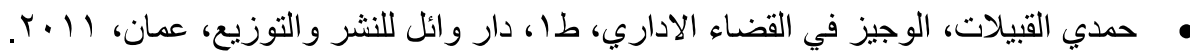

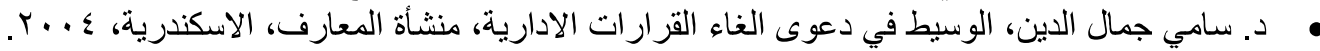

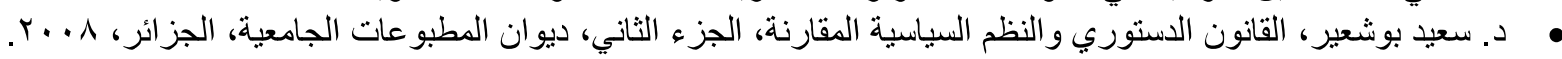

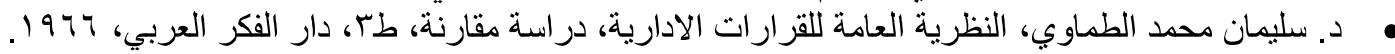

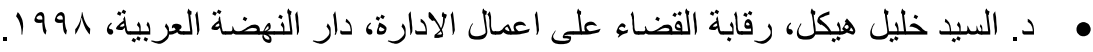
• .. عبد الغني بسيوني عبد الله، وقف تنفيذ القزار الاداري في احكام القضاء الاداري، طاسب، منشورات الحلبي الحقوقية،

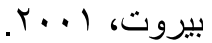

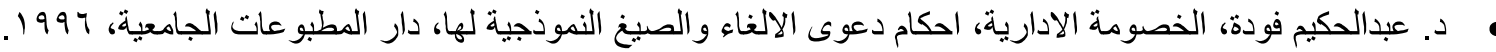

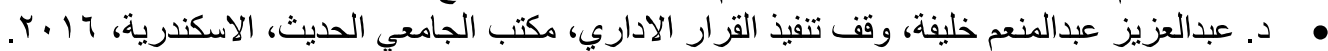

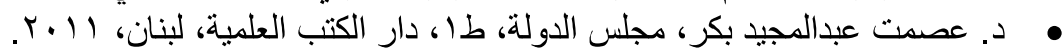

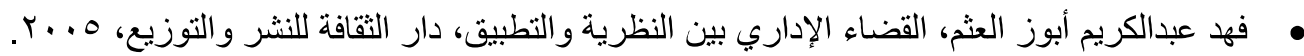

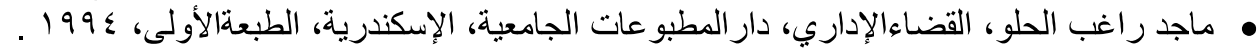

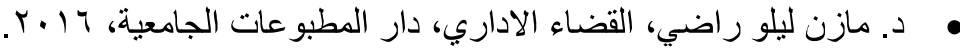

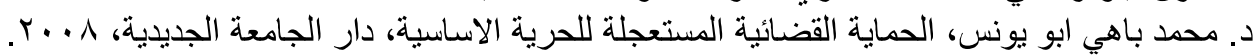

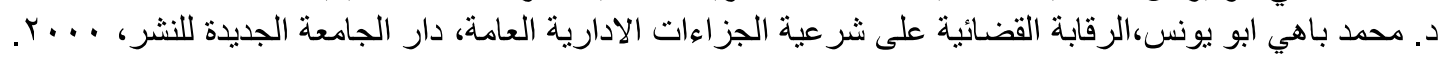

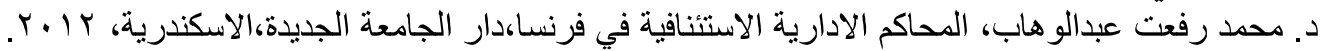

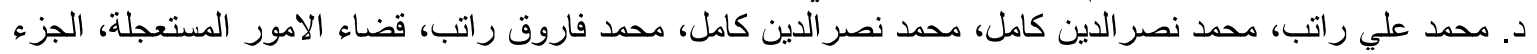

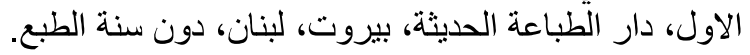

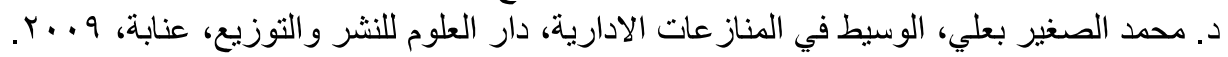

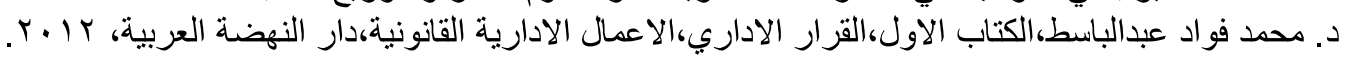

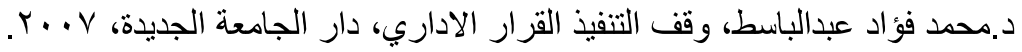

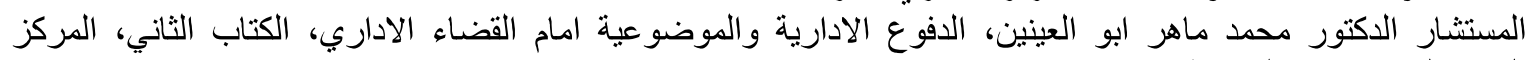

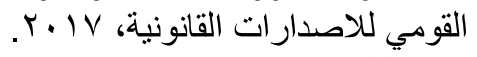
القوانين والثرارات

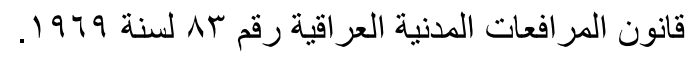

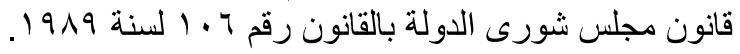

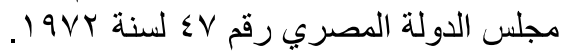

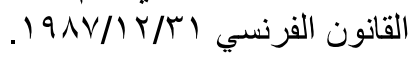

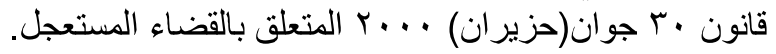

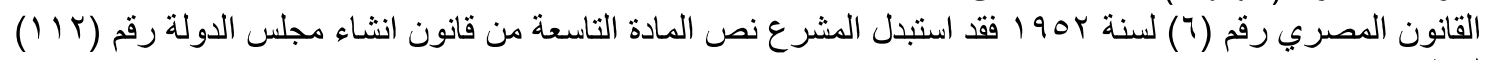

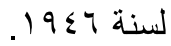

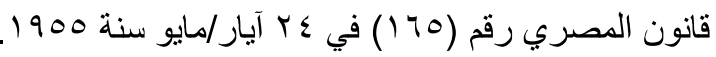

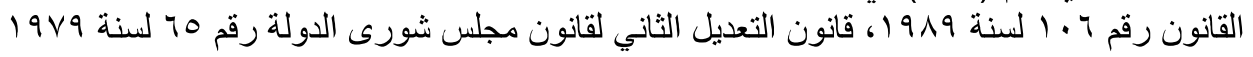

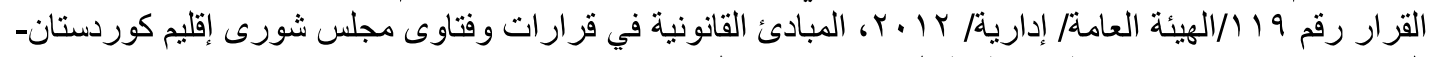

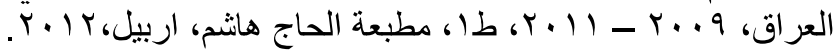

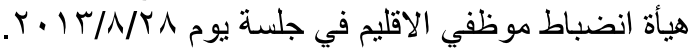

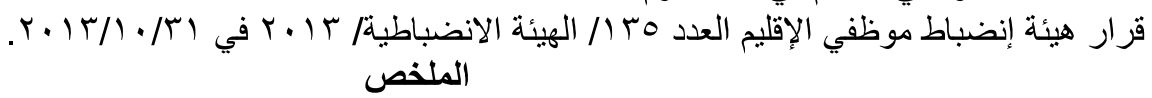

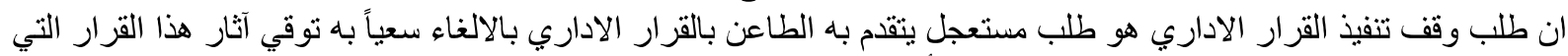

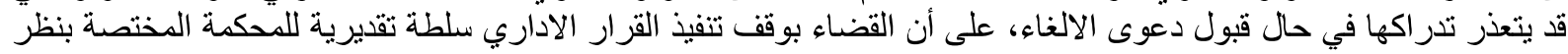

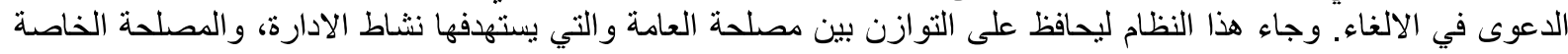

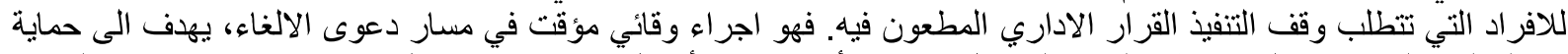

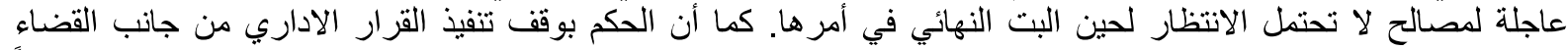

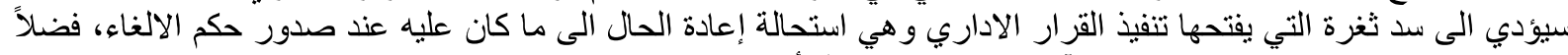

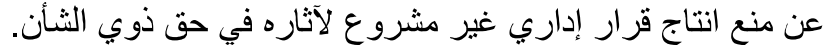

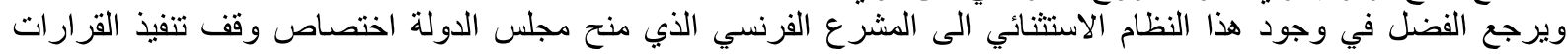

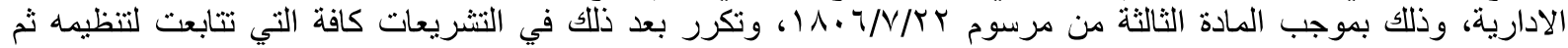

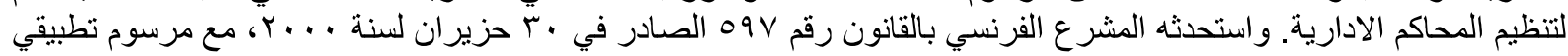

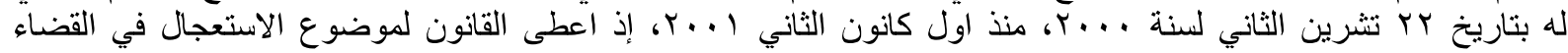
الاداري حقه من الاهتمام و التنجديد. 


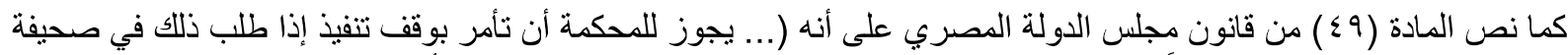

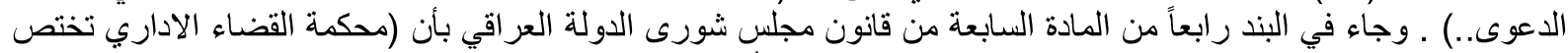

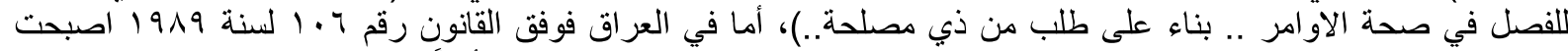

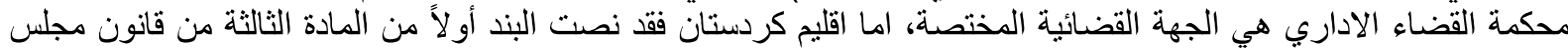

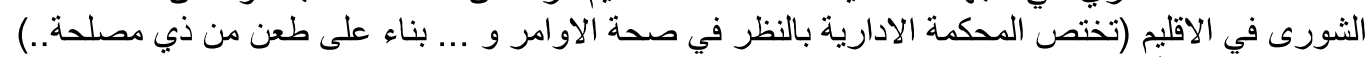

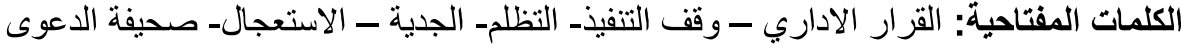
بوخته

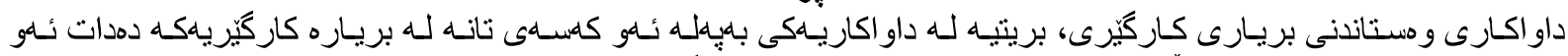

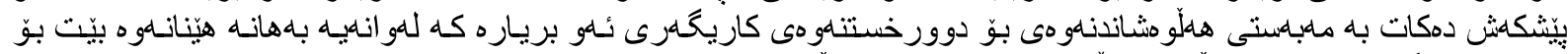

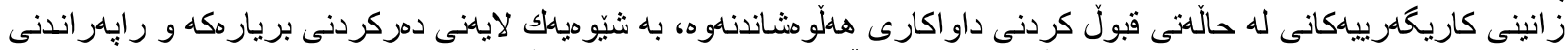

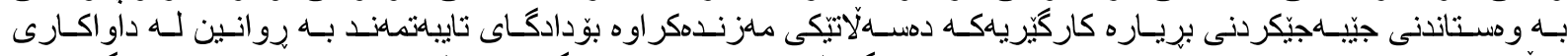

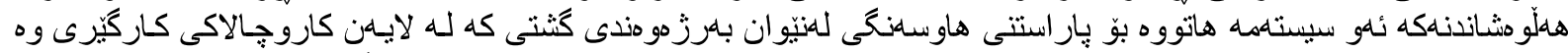

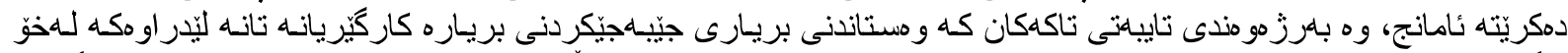

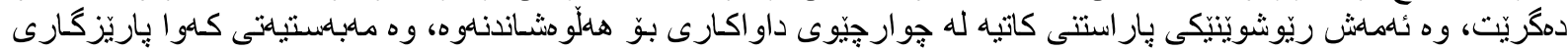

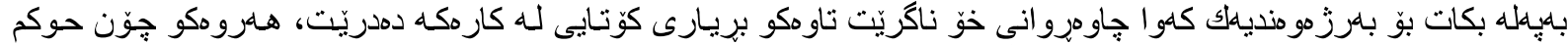

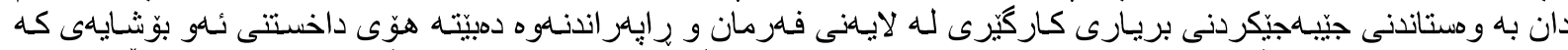

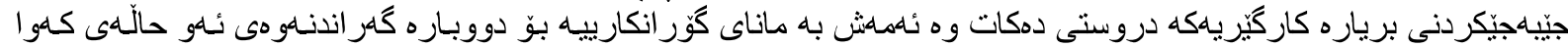

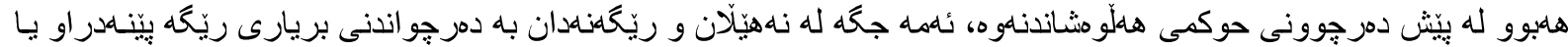

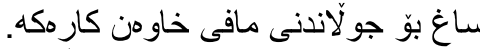

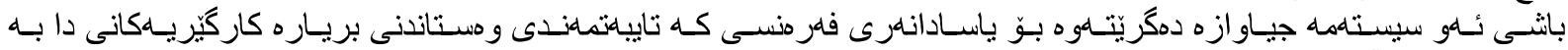

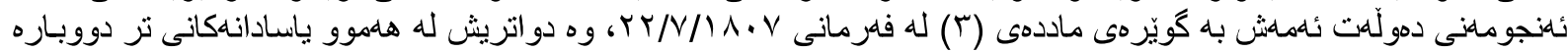

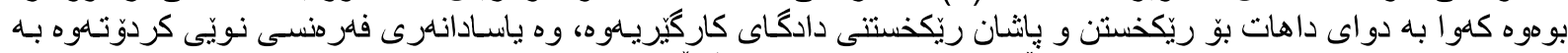

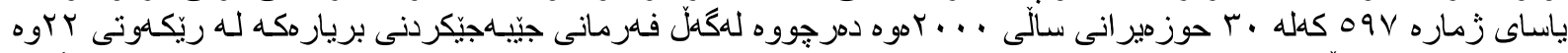

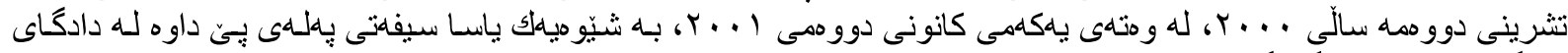

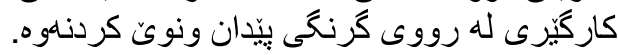

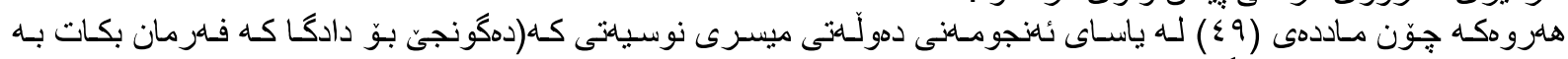

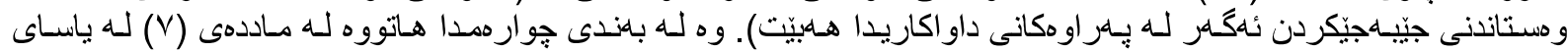

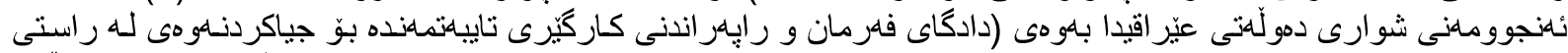

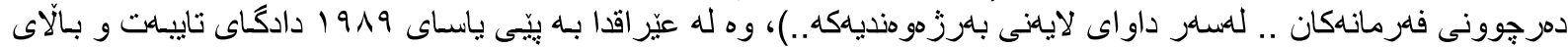

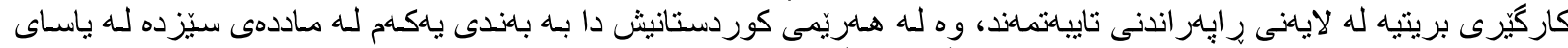

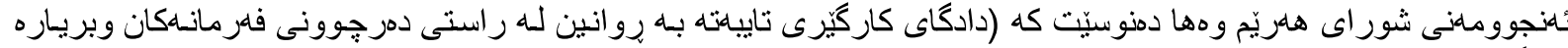

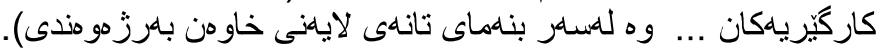

Abstract

The request to suspend the implementation of the administrative decision is an urgent request submitted by the appellant to the administrative decision to cancel. This is done in order to prevent the effects of the decision, which might be unrecognizable in the event of accepting the cancellation lawsuit. Provided that the judiciary to suspend the implementation of the administrative decision is a discretionary authority of the court competent to consider the case for cancellation. This system exists to maintain the balance between the public interest and the target of the administration activity, and the private interest of individuals that require a stay of execution the contested administrative decision. It is a temporary preventive measure in the course of the cancellation lawsuit, aimed at urgent protection of interests that cannot wait for a final decision.

The existence of this exceptional system has resulted in the French legislator to grant the State Council the power to stop the implementation of administrative decisions, in accordance with Article III of Decree 7/22/1806. Likewise, all legislations have continued the procedure to organize the administrative courts. The French legislator have adopted the procedure through introduced Law No. 597 of June 30, 2000.An implementing decree issued on November 22, 2000. In fact, since January 1, 2001, the law has given the subject of urgency in the administrative judiciary its right to attention and renewal. 
Article 49 of the Egyptian Council of State Law stipulates that (... the court may order a stay of execution if requested in the lawsuit ..). Paragraph 4 of Article 7 of the Law of the Consultative Council of the Iraq states that (the Administrative Court of Judgment is competent to rule on the validity of orders. At the request of an interested party ...) As for Iraq, according to Law No. 106 of 1989, the Administrative Judicial Court became the competent judicial authority, while the Kurdistan Region stipulated the first clause of Article 3 of the Consultative Council Law in the region (the administrative court is competent to consider Correctness of orders and ... upon appeal by an interested party ...).

Keywords: the administrative decision, suspend the implementation, grievance, seriousness, urgency, the lawsuit. 